\title{
Comparison of microstructure and mechanical properties of ultra-narrow gap laser and gas-metal-arc welded S960 high strength steel
}

DOI:

10.1016/j.optlaseng.2016.11.011

\section{Document Version}

Accepted author manuscript

Link to publication record in Manchester Research Explorer

Citation for published version (APA):

Guo, W., Li, L., Dong, S., Crowther, D., \& Thompson, A. (2017). Comparison of microstructure and mechanical properties of ultra-narrow gap laser and gas-metal-arc welded S960 high strength steel. Optics and Lasers in Engineering, 91, 1-15. https://doi.org/10.1016/j.optlaseng.2016.11.011

Published in:

Optics and Lasers in Engineering

\section{Citing this paper}

Please note that where the full-text provided on Manchester Research Explorer is the Author Accepted Manuscript or Proof version this may differ from the final Published version. If citing, it is advised that you check and use the publisher's definitive version.

\section{General rights}

Copyright and moral rights for the publications made accessible in the Research Explorer are retained by the authors and/or other copyright owners and it is a condition of accessing publications that users recognise and abide by the legal requirements associated with these rights.

\section{Takedown policy}

If you believe that this document breaches copyright please refer to the University of Manchester's Takedown Procedures [http://man.ac.uk/04Y6Bo] or contact uml.scholarlycommunications@manchester.ac.uk providing relevant details, so we can investigate your claim.

\section{OPEN ACCESS}




\section{Comparison of microstructure and mechanical properties of ultra-narrow gap laser and gas-metal-arc welded S960 high strength steel}

Wei Guo ${ }^{a}$,

guoweiq@hotmail.com

$\operatorname{Lin~} \mathrm{Li}^{\mathrm{a}}$

Shiyun Dong

Dave Cro

Alan Thompson

aLaser Processing Research Centre, School of Mechanical, Aerospace and Civil Engineering, The University of Manchester, Sackville Street, Manchester,Manchester M13 9PL9PL, UK

bational Key Lab for Remanufacturing, 21 Dujiakan, Fengtai, Beijing, 100072Beijing 100072, China

'Tata Steel, Research \& Development, Swinden Technology Centre, Moorgate, Rotherham, South Yorkshire,Yorkshire S60 3AR3AR, UK

${ }^{*}$ Corresponding author

\section{Abstract}

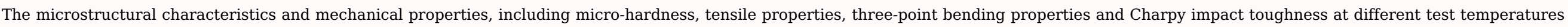

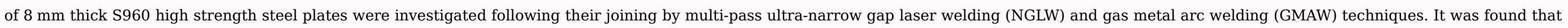

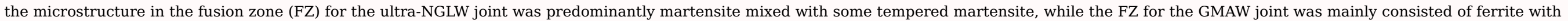

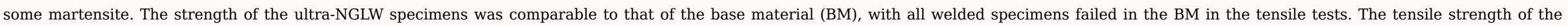

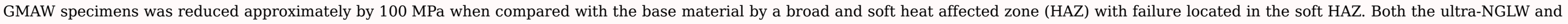
GMAW specimens performed well in three-point bending tests. The GMAW joints exhibited better impact toughness than the ultra-NGLW joints.

Keywords: asAs welded condition; heatHeat input;

\section{Introduction}

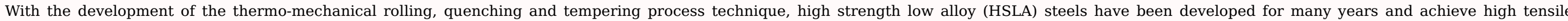

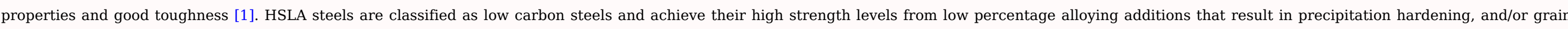

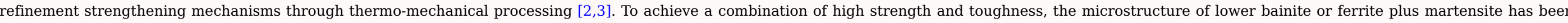

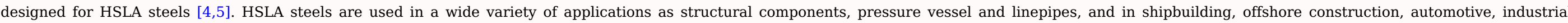

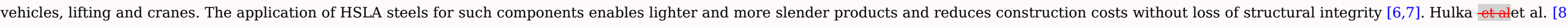
reported that under tensile stresses the plate thickness can be reduced by around 60\% by using the steel grade S960 instead of S355.

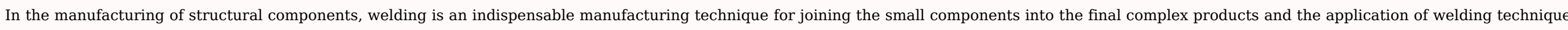

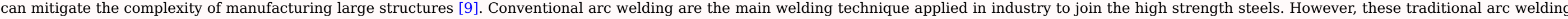

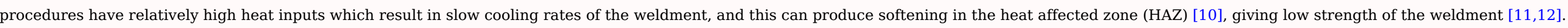




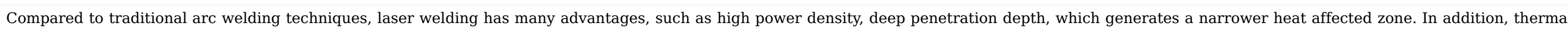

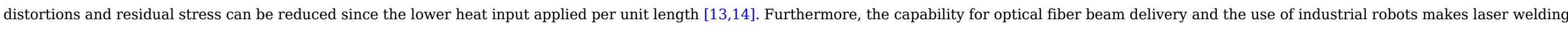

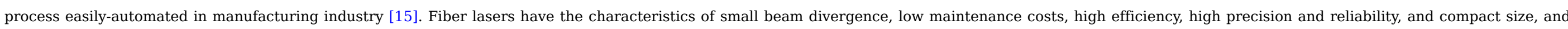
consequently they have attracted more attention over the last decade for cutting, welding and cladding applications [16-18].

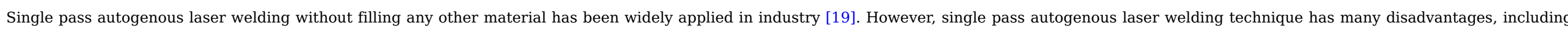

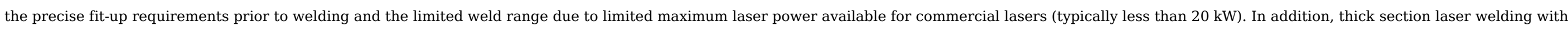
a single pass approach often results in porosity, molten material dropout, cracking, and mis-tracking of weld seams [20-22].

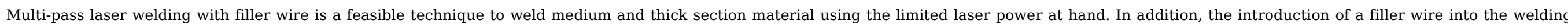

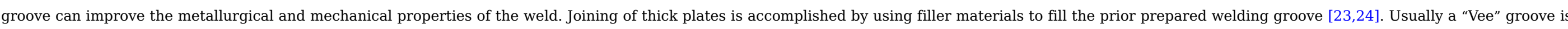

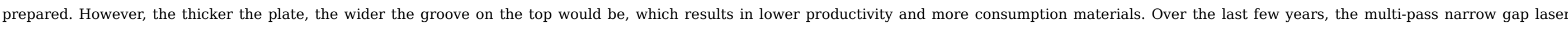

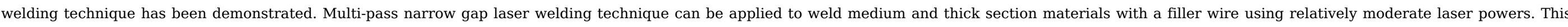

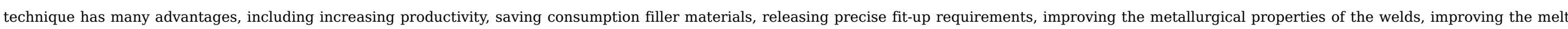
sagging problem, and reducing residual stress and distortion [25-27].

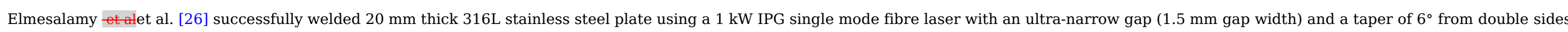

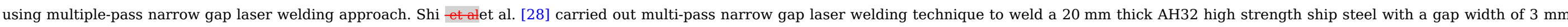
and taper of $5^{\circ}$ and $10^{\circ}$. However, some porosity and lack of fusion defects still existed in the weld beads.

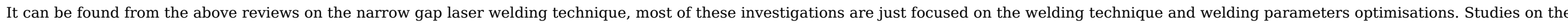
microstructures evolution and mechanical properties of the narrow gap laser welded materials are scarce.

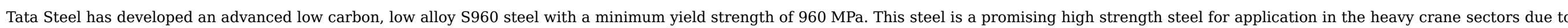

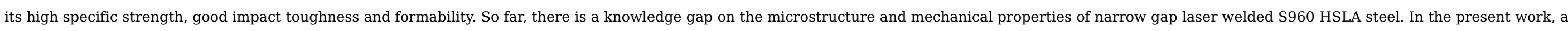

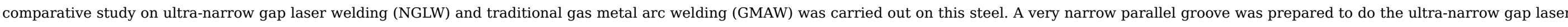

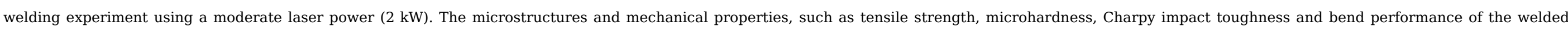
components were investigated and compared for the above two welding techniques in the as-welded condition.

\section{Material and experimental procedures}

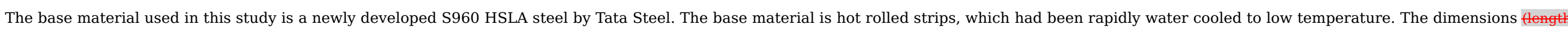

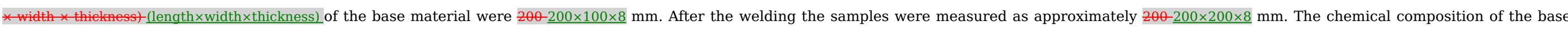
material (BM) is shown in Table 1. The carbon equivalent (CE) of the investigated steel is calculated according to the following equation [16]:

$\mathrm{CE}=\mathrm{C}+\mathrm{Mn} / 6+(\mathrm{Cr}+\mathrm{Mo}+\mathrm{V}) / 5+(\mathrm{Ni}+\mathrm{Cu}) / 15$

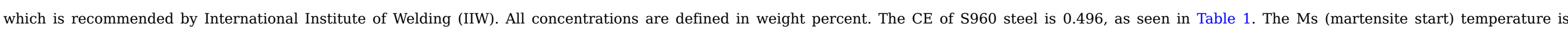

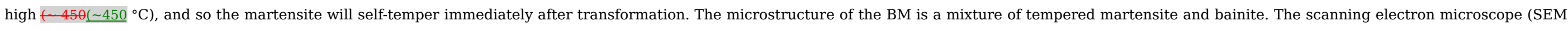

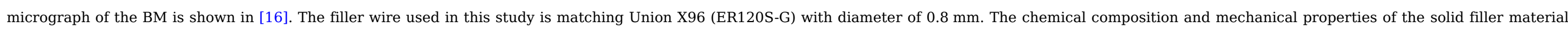
Union X96 are depicted in Tables 2 and 3, respectively. The CE of the Union X96 filler wire is 0.79.

Table 1 Chemical composition of S960 steel (wt. \%).(wt\%). 


\begin{tabular}{|c|c|c|c|c|c|c|c|c|c|}
\hline C & $\mathrm{Mn}$ & $\mathrm{P}$ & $\mathrm{S}$ & $\mathrm{N}$ & B & $\mathrm{Ca}$ & $\mathrm{Si}$ & $\mathrm{Al}$ & $\mathrm{Cu}$ \\
\hline 0.088 & 1.51 & 0.008 & 0.002 & 0.0089 & 0.0022 & 0.012 & 0.055 & 0.033 & 0.014 \\
\hline Sn & $\mathrm{Cr}$ & $\mathrm{Ni}$ & Mo & $\mathrm{Ti}$ & $\mathrm{Nb}$ & V & $\mathrm{Fe}$ & CE & \\
\hline 0.001 & 0.472 & 0.023 & 0.248 & 0.025 & 0.040 & 0.050 & Bal. & 0.496 & \\
\hline
\end{tabular}

Table 2 Chemical composition of the Union X96 filler wire (wt.\%).(wt\%). alt-text: Table 2

\begin{tabular}{|c|c|c|c|c|c|c|c|}
\hline C & $\mathrm{Si}$ & $\mathrm{Mn}$ & $\mathrm{Cr}$ & Mo & $\mathrm{Ni}$ & $\mathrm{Fe}$ & CE \\
\hline 0.12 & 0.80 & 1.90 & 0.45 & 0.55 & 2.35 & Bal. & 0.79 \\
\hline
\end{tabular}

Table 3 The mechanical properties of the Union X96 filler wire.

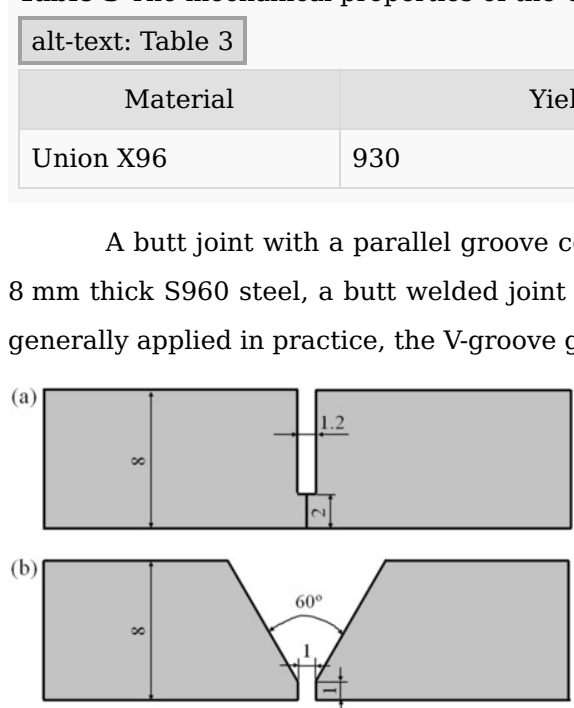

Fig. 1 Schematic of welding groove: (a) the groove shape for ultra-NGLW, (b) the groove shape for GMAW.

alt-text: Fig. 1

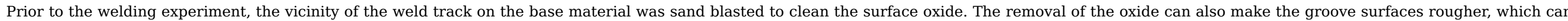

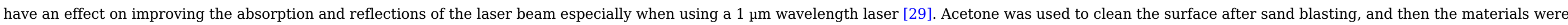
clamped on the work table to ensure adequate restraint. Both the ultra-NGLW and GMAW were carried out perpendicular to the rolling direction of the base material.

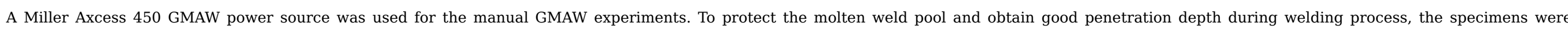

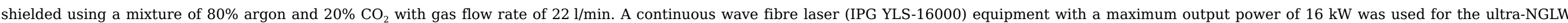
experiments. The detailed parameters of the fiber laser system and the schematic of the ultra-NGLW process setup are shown in [30].

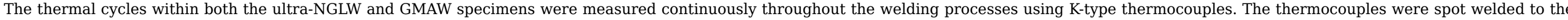

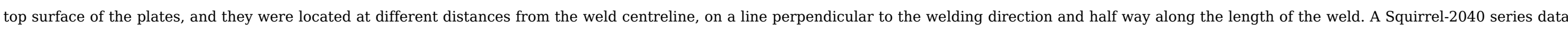




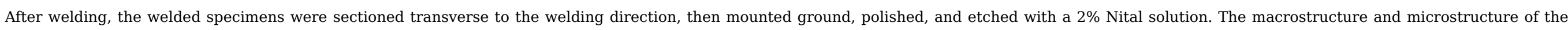
welded joints investigation were performed using a KEYENCE VHX-500F optical microscope and Philips XL 30 scanning electron microscope (SEM).

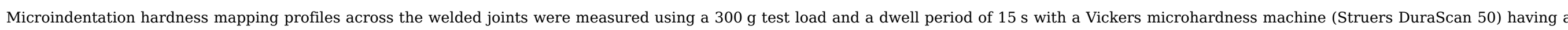

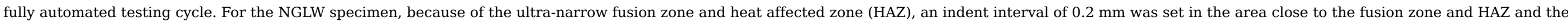

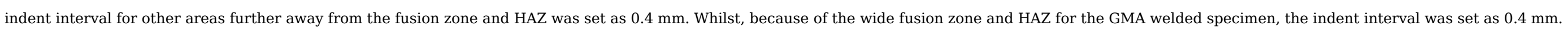

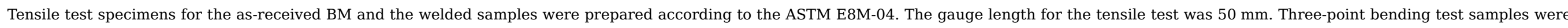

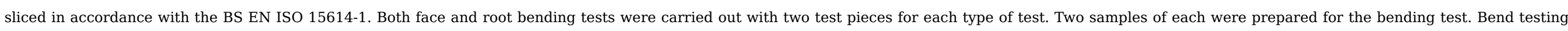

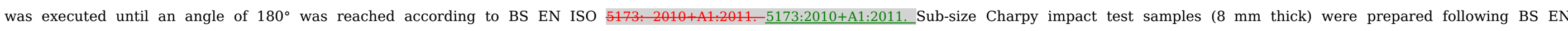

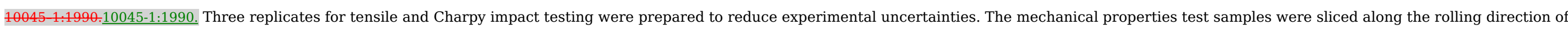

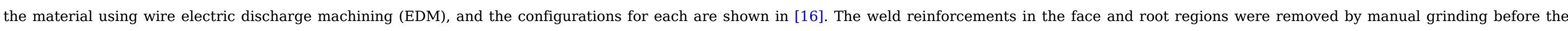

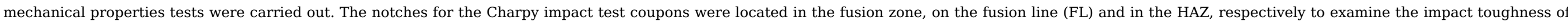

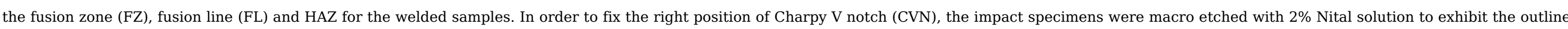

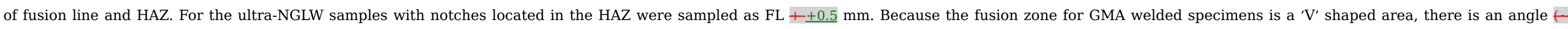

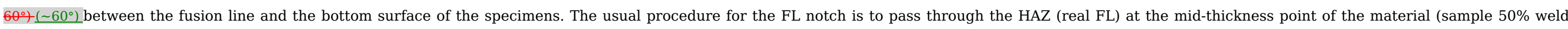

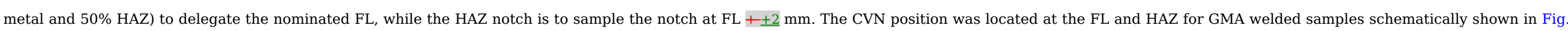

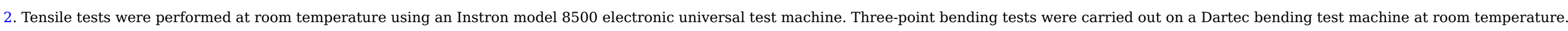

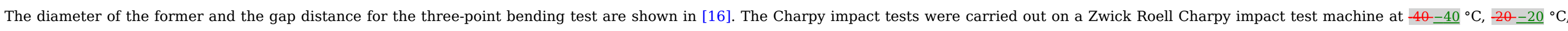

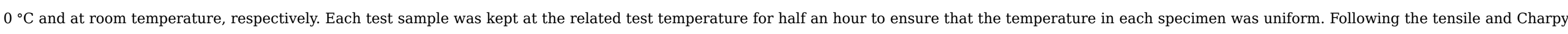

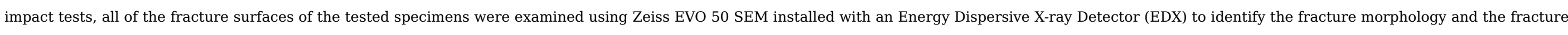
mechanisms.

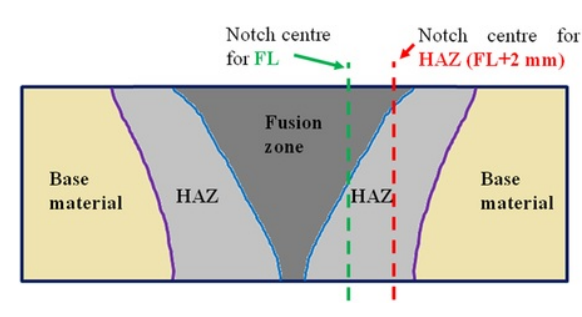

Fig. 2 Schematic representation of the sample with notch at the FL and in the HAZ for GMAW samples.

alt-text: Fig. 2

\section{Results and Điscussiondiscussion}

\subsection{Welding parameters}

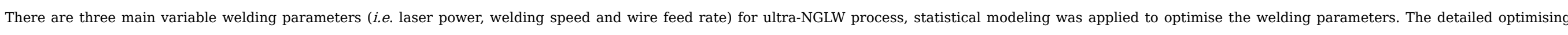

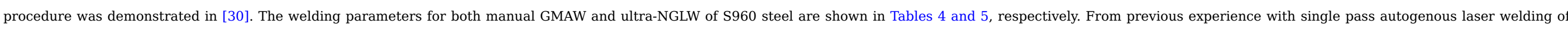

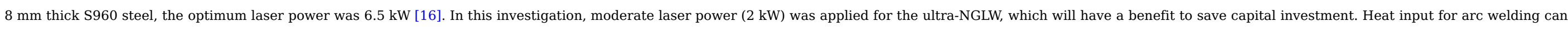

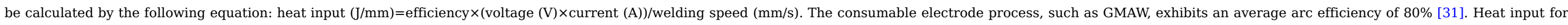




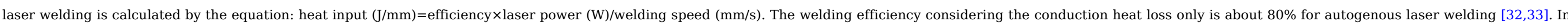
addition, some beam reflection from the filler wire takes place in the ultra-NGLW process, which could result in 30\% loss of energy applied into the workpieces [34].

Table 4 Optimised GMAW parameters for $8 \mathrm{~mm}$ thick S960 steel.

alt-text: Table 4

\begin{tabular}{|c|c|c|c|c|c|c|}
\hline Welding pass & Voltage (V) & Current (A) & Welding speed $(\mathrm{m} / \mathrm{min})$ & Wire feeding rate $(\mathrm{m} / \mathrm{min})$ & Shielding gas flow (l/min) & Heat input $(\mathrm{kJ} / \mathrm{mm})$ \\
\hline First & 27 & 175 & 0.4 & 4.0 & 22 & 0.57 \\
\hline Second & 27 & 165 & 0.46 & 4.0 & 22 & 0.46 \\
\hline Third (torch weave) & 27 & 168 & 0.26 & 4.0 & 22 & 0.84 \\
\hline
\end{tabular}

Table 5 Optimised ultra-NGLW parameters for $8 \mathrm{~mm}$ thick S960 steel.

\begin{tabular}{|c|c|c|c|c|c|c|c|}
\hline Welding pass & Power $(\mathrm{kW})$ & Welding speed (m/min) & Wire feeding rate (m/min) & Top shielding gas flow (l/min) & Back shielding gas flow (1/min) & Focal position $(\mathrm{mm})$ & Heat input $(\mathrm{kJ} / \mathrm{mm})$ \\
\hline Root pass & 2 & 1.2 & - & 12 & 8 & -6 & 0.08 \\
\hline Filling pass & 2 & 0.6 & 3.3 & 12 & 8 & 0 & 0.11 \\
\hline Filling pass & 2 & 0.6 & 3.3 & 12 & 8 & 0 & 0.11 \\
\hline
\end{tabular}

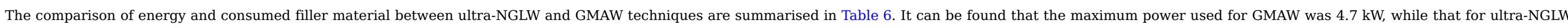

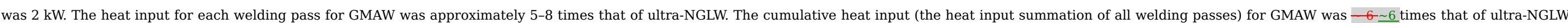
The welding speed for ultra-NGLW was $-1.5 \underline{\sim 1.5}$ times that of GMAW. The consumed filler material for GMAW was $-6 \underline{-6}$ times that of ultra-NGLW.

Table 6 Comparison of energy and consumed filler material between ultra-NGLW and GMAW.

\begin{tabular}{|c|c|c|c|c|c|}
\hline Welding technique & Maximum power used (kW) & No. of welding passes & welding speed (m/min) & Consumed filler material (g) & Cumulative heat input $(\mathrm{kJ} / \mathrm{mm})$ \\
\hline GMAW & 4.7 & 3 & 0.4 & 89 & 1.87 \\
\hline Ultra-NGLW & 2 & 3 & 0.6 & 16 & 0.3 \\
\hline
\end{tabular}

\subsection{Macrostructure of the welded joints}

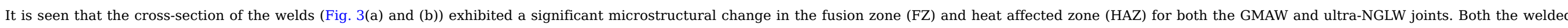

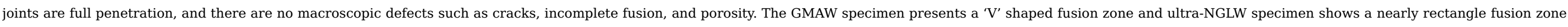

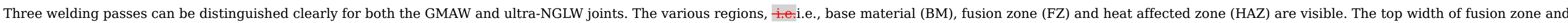

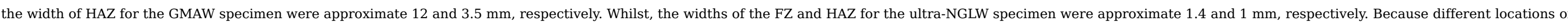

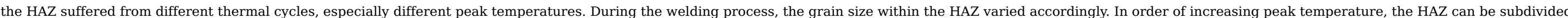

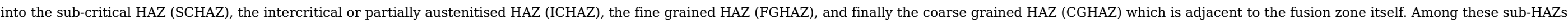
the CGHAZ experienced the highest peak temperature, which caused an increase in the grain size in this sub-zone. 


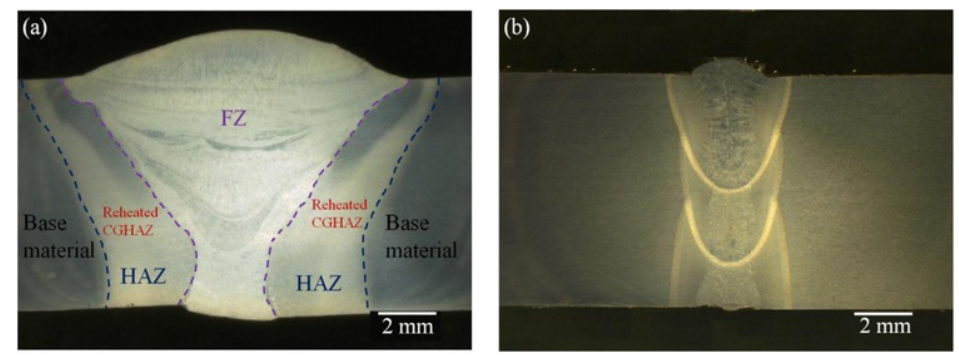

Fig. 3 Cross-section profiles the welded joints, (a) GMAW, (b) ultra-NGLW.

\section{alt-text: Fig. 3}

\subsection{Thermal cycles throughout the welding processes}

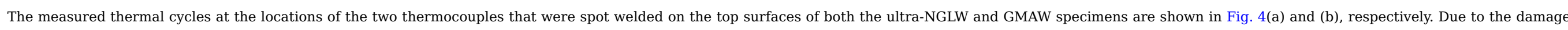

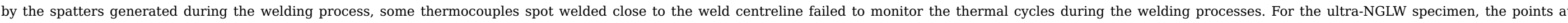

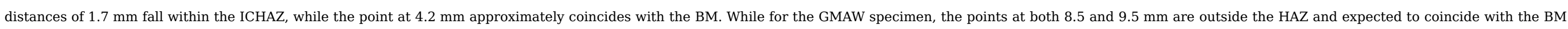

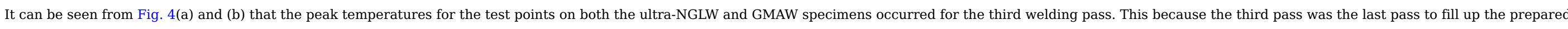

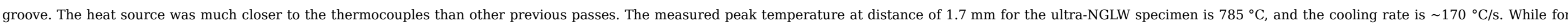

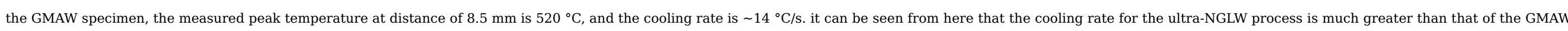
process.
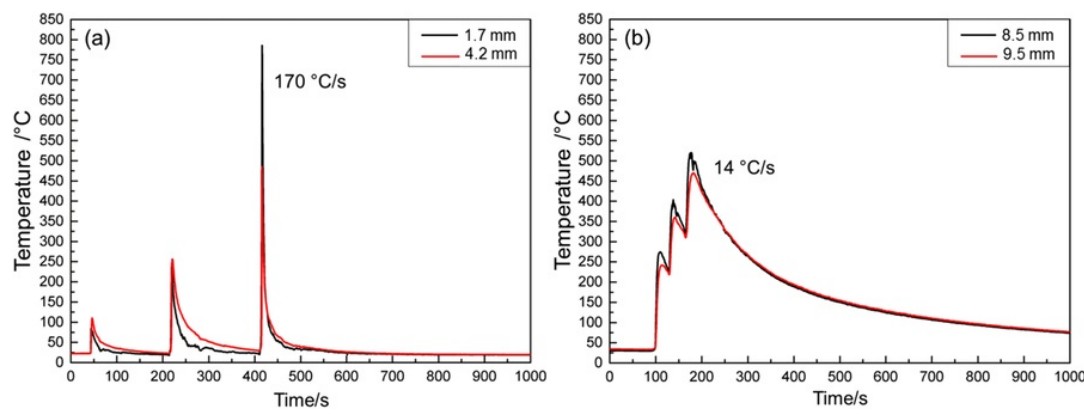

Fig. 4 Comparison of measured temperature histories at different distance from the weld centrelines, (a) ultra-NGLW, (b) GMAW.

\section{alt-text: Fig. 4}

\subsection{Microstructures in different sub zones}

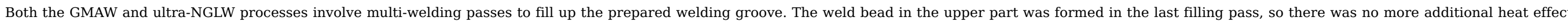

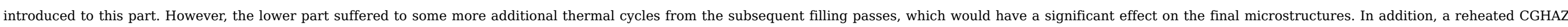
was generated in the GMAW joint. This sub-zone is located in the middle of the wide HAZ and surrounds the 'Vee' shaped FZ, as indicated in Fig. 3(a)

\subsubsection{Microstructures in different sub zones of the ultra-NGLW joint}

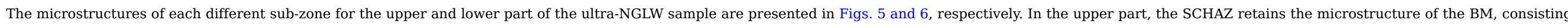

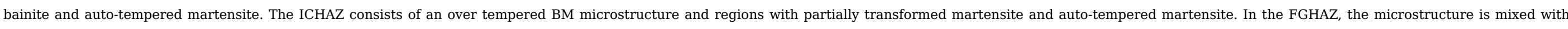

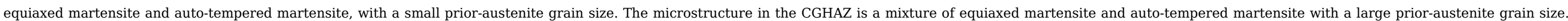



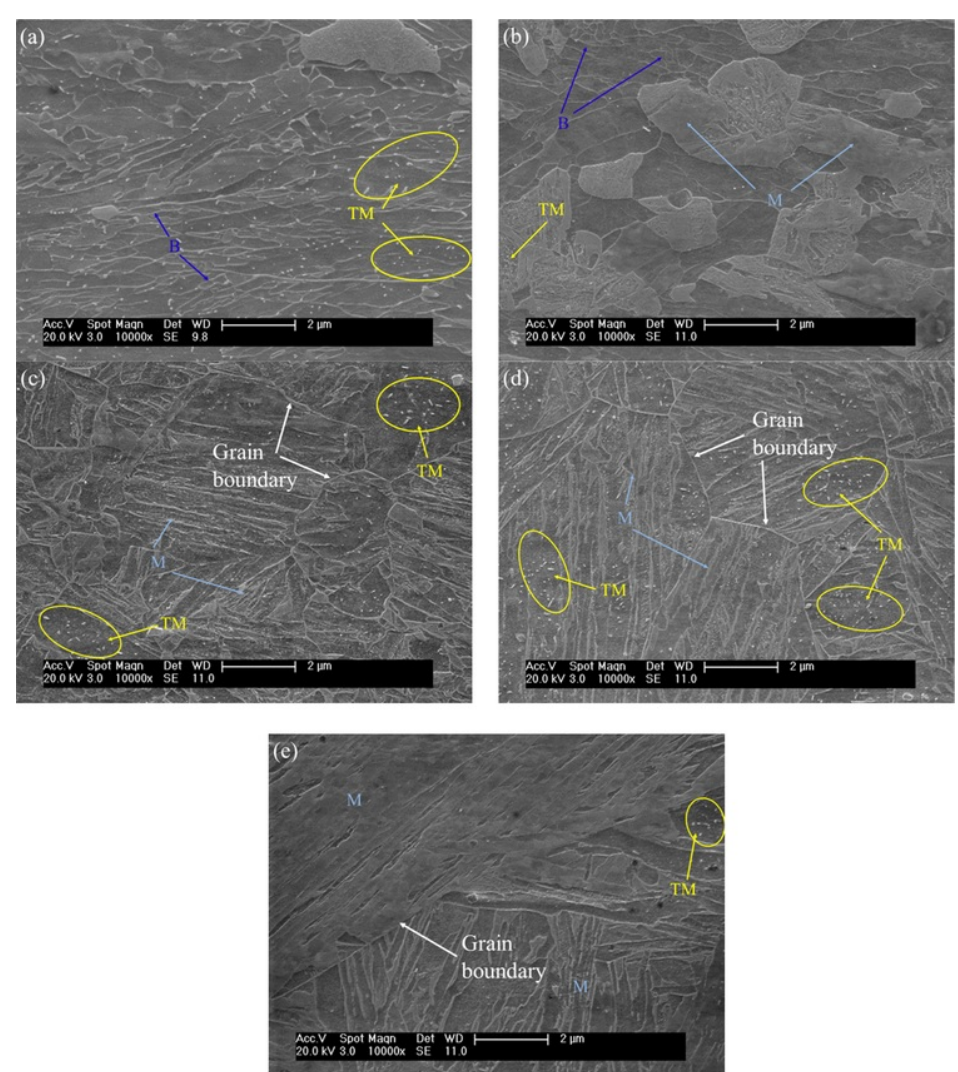

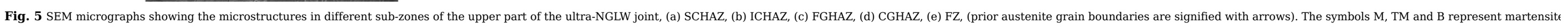
tempered martensite and bainite, respectively.

alt-text: Fig. 5 


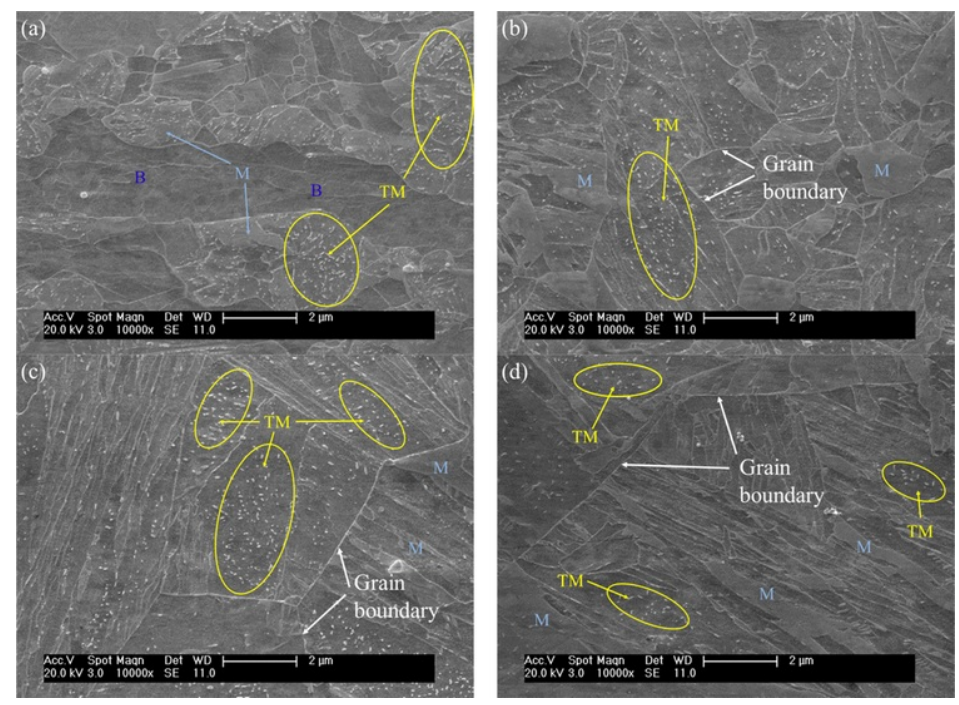

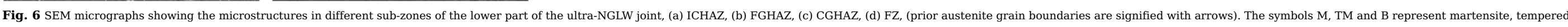
martensite and bainite, respectively.

alt-text: Fig. 6

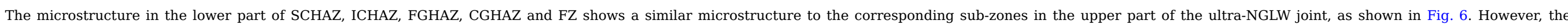

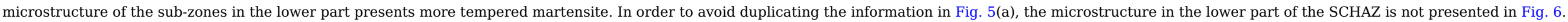

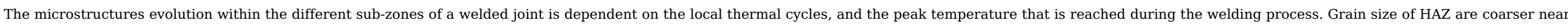

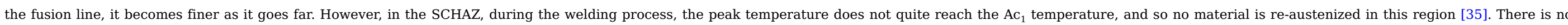

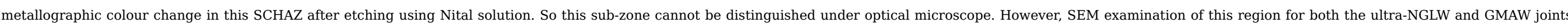
indicated that the phases apparent in this sub-zone retained the microstructure of the BM, mixed with tempered martensite and bainite, as is shown in Fig. 5(a) and Fig. 7(a). 


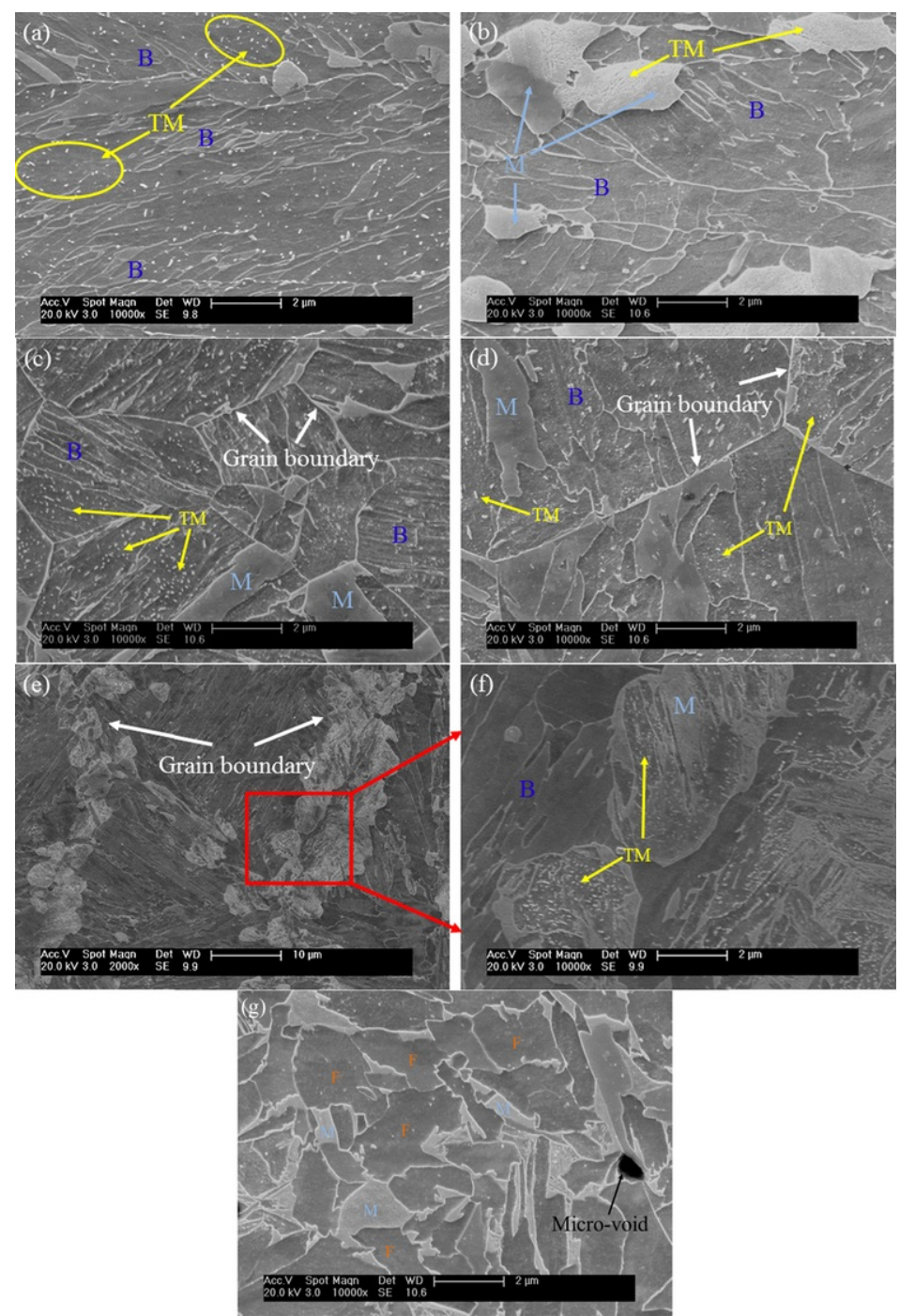

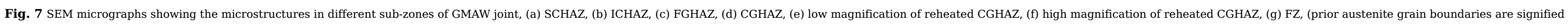
with arrows). The symbols M, TM, B and F represent martensite, tempered martensite, bainite and ferrite, respectively.

alt-text: Fig. 7

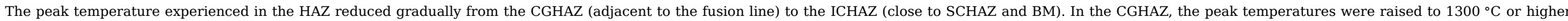

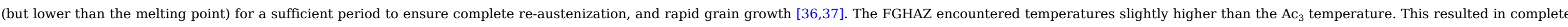

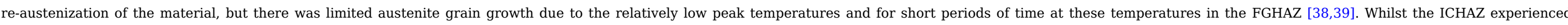

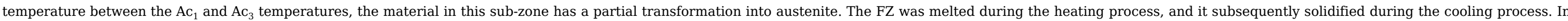
addition, very large grain size austenite was generated in the FZ.

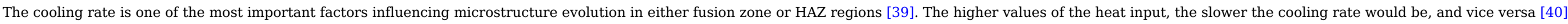




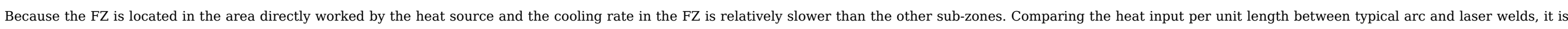

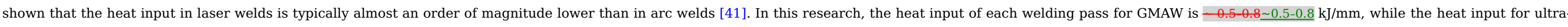

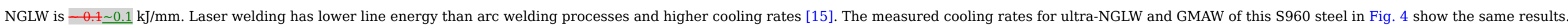

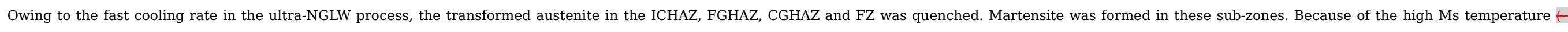

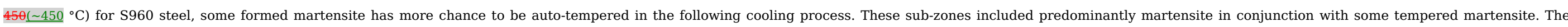

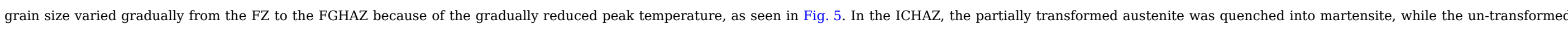

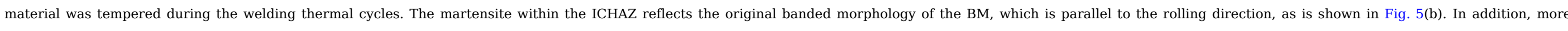

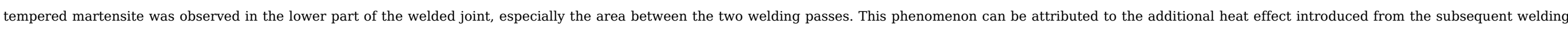
pass to the prior welding pass. This newly generated thermal cycle has a tempering effect on the prior welding pass.

\subsubsection{Microstructures in different sub zones of the GMAW joint}

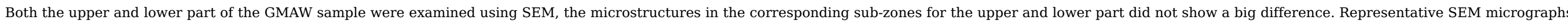

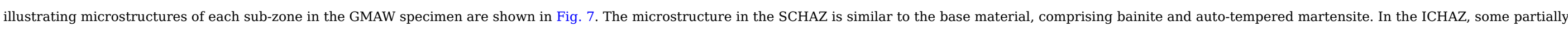

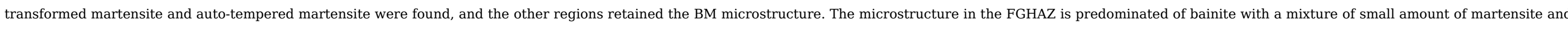

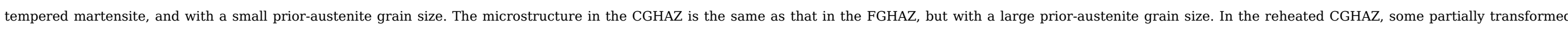

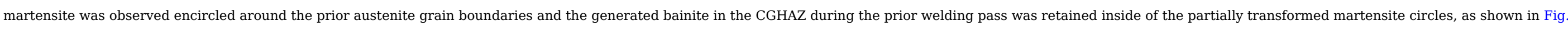

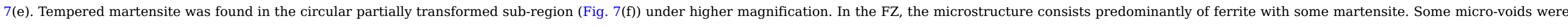
found in the FZ because of the drop off of the inclusions during the polishing process.

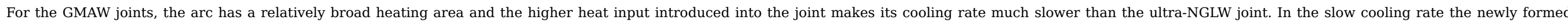

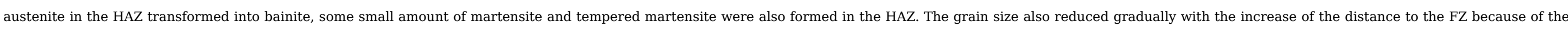

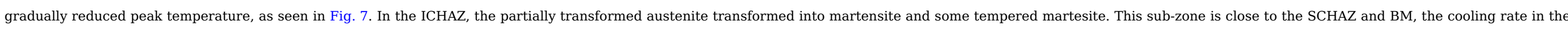

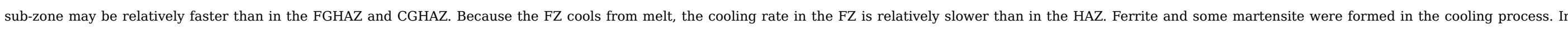

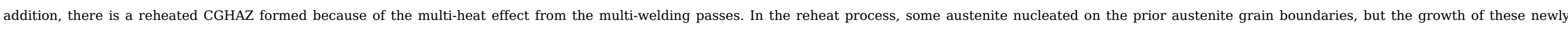

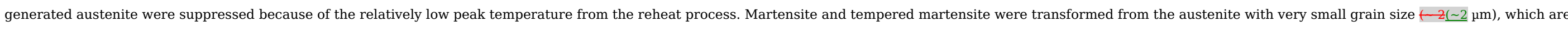
encircled around the prior austenite grain boundaries. While the generated bainite in the CGHAZ was retained, which were inside the partially transformed martensite circle, as seen in Fig. 7(e) and (f).

\subsection{Microhardness}

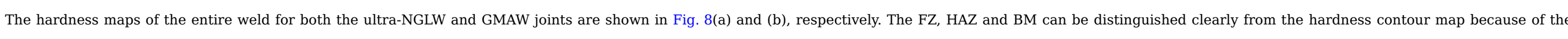

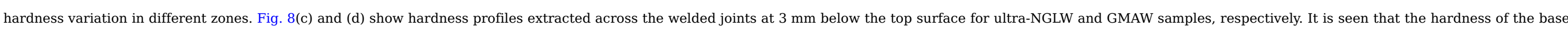

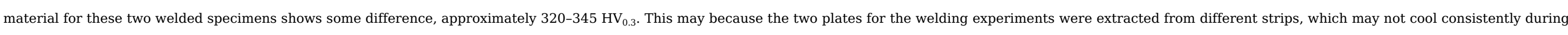

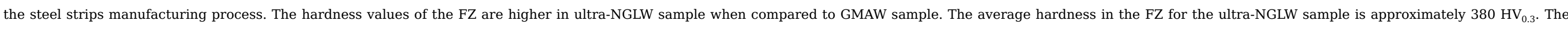

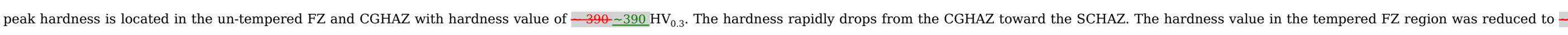

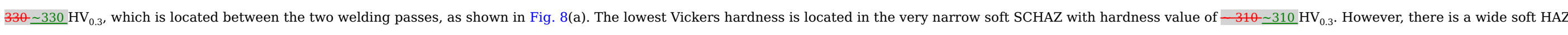

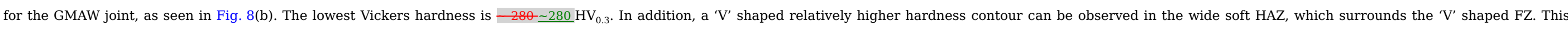

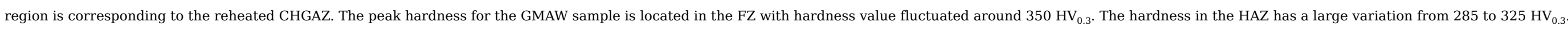



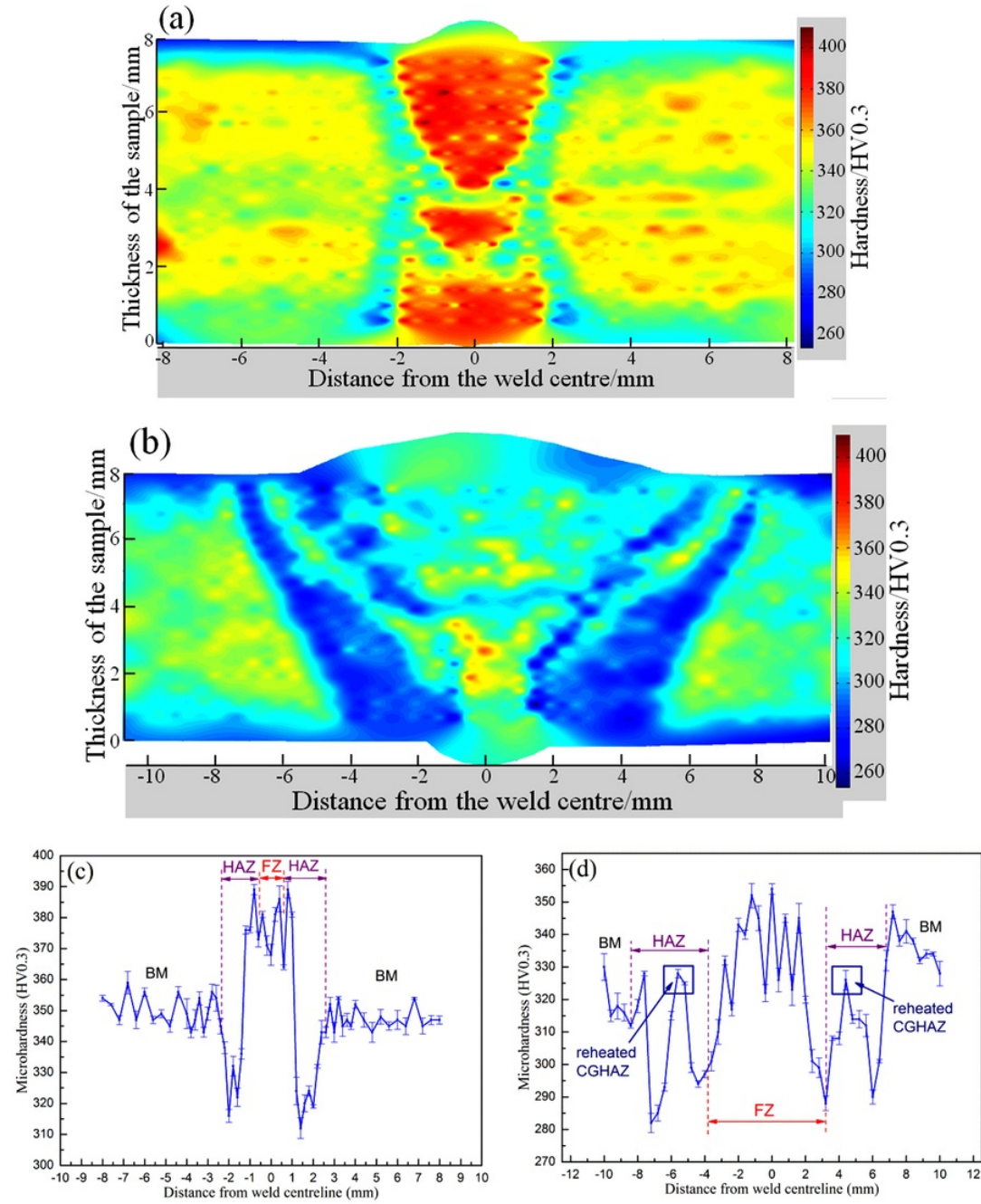

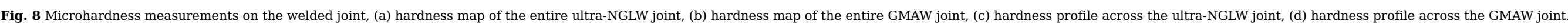
alt-text: Fig. 8

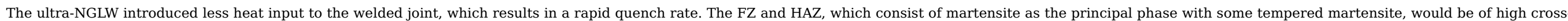

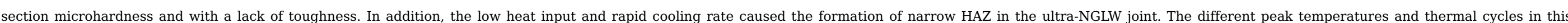

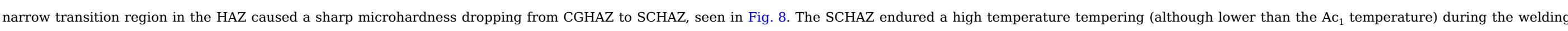

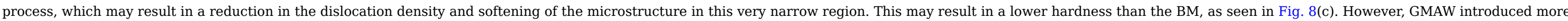

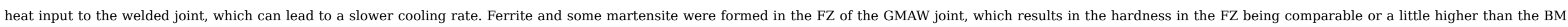

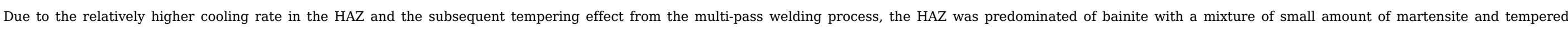
martensite, which results in a broader HAZ than ultra-NGLW joint and a much wider and softer HAZ than the ultra-NGLW joint.

\subsection{Tensile and bending properties}




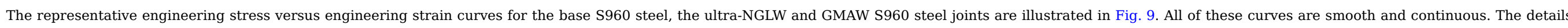

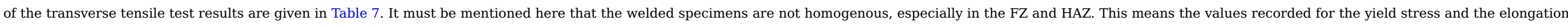

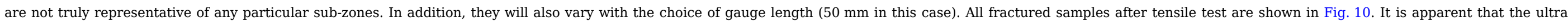

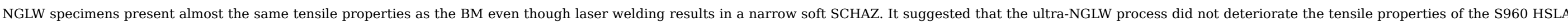

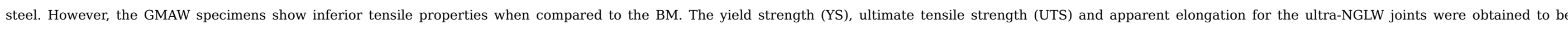

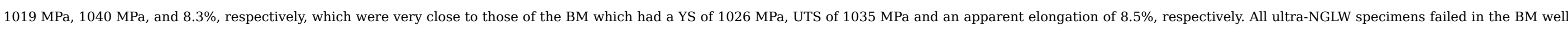

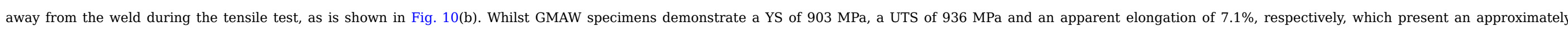
$100 \mathrm{MPa}$ lower strength and 1.4\% less elongation when compared to the BM. All tensile failures for the GMAW specimens were in the soft HAZ, as is shown in Fig. 10(c).

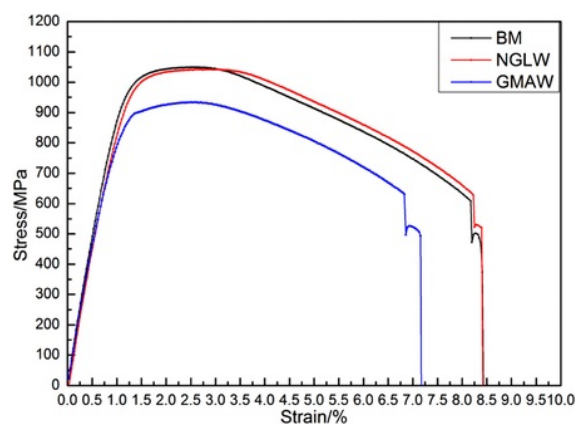

Fig. 9 Representative engineering stress versus engineering strain curves for base S960 steel, the ultra-NGLW and GMAW S960 steel joints.

alt-text: Fig. 9

Table 7 Tensile properties for the base material, the ultra-NGLW and the GMAW specimens.

alt-text: Table 7

\begin{tabular}{|c|c|c|c|}
\hline Test specimens & Yield strength (MPa) & Tensile strength (MPa) & Elongation (\%) \\
\hline Base material $(8 \mathrm{~mm})$ & $1026 \pm 7$ & $1035 \pm 11$ & $8.5 \pm 0.3$ \\
\hline NGLW (8 mm) & $1019 \pm 8$ & $1040 \pm 11$ & $8.3 \pm 0.3$ \\
\hline GMAW (8 mm) & $903 \pm 7$ & $936 \pm 9$ & $7.1 \pm 0.8$ \\
\hline
\end{tabular}




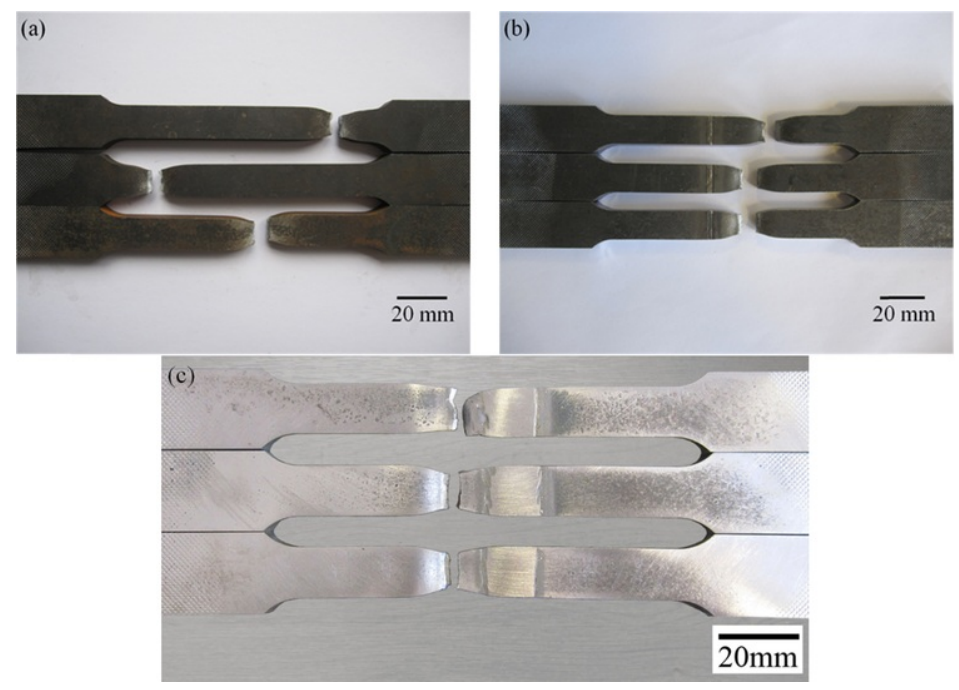

Fig. 10 Fracture location of the tensile test specimens, (a) base material, (b) ultra-NGLW samples, (c) GMAW samples. alt-text: Fig. 10

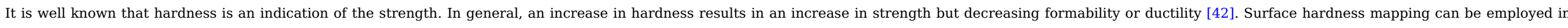

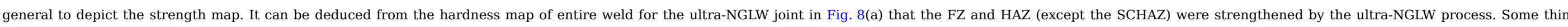

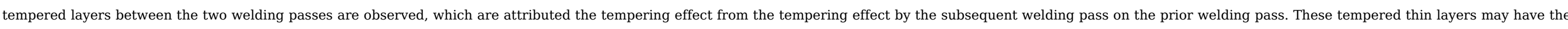
same or comparable strength as the BM. However, a very narrow SCHAZ can also be observed from the hardness mapping results, which would be the weakest region for the ultra-NGLW joint.

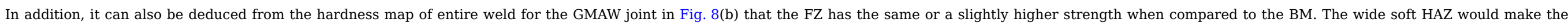
welded joint lose strength. However, the very thin ' $\mathrm{V}$ ' shaped reheated CHGAZ may strengthen the wide soft HAZ a little.

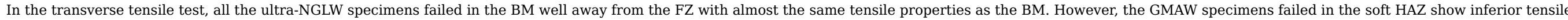

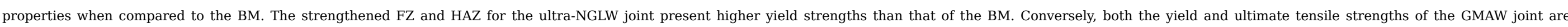

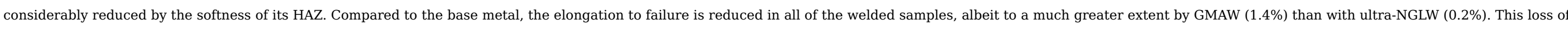

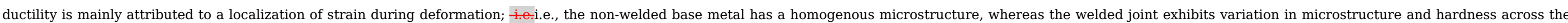

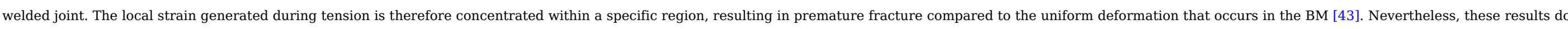

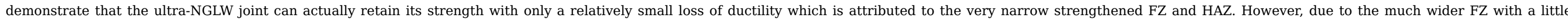
strengthened region for GMAW specimens, the GMAW specimens show much reduction on the elongation than the ultra-NGLW specimens.

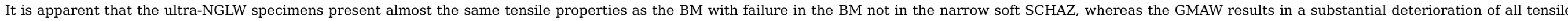

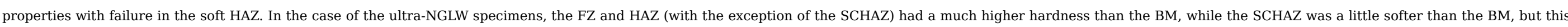

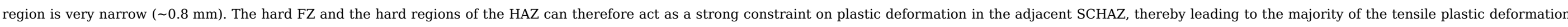

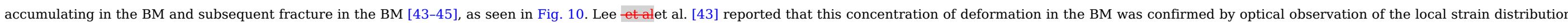

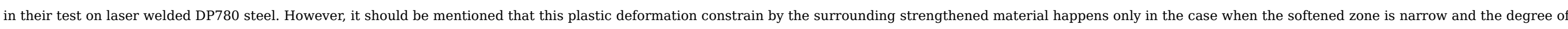

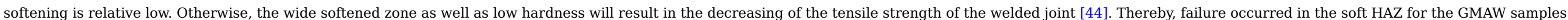

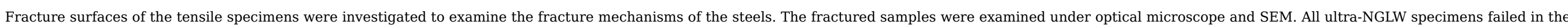




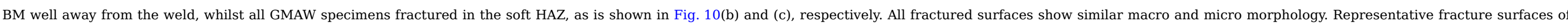

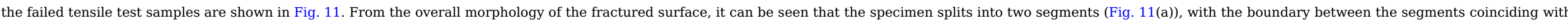

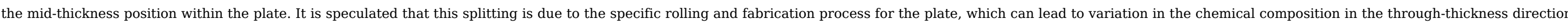

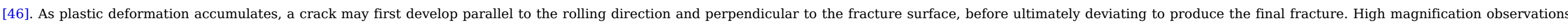

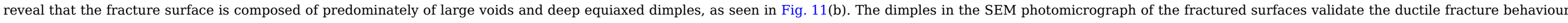

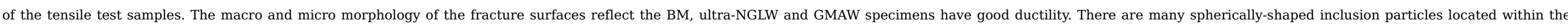

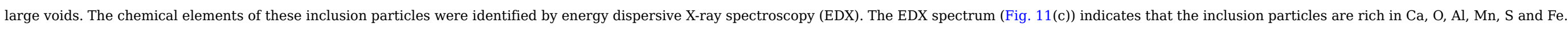
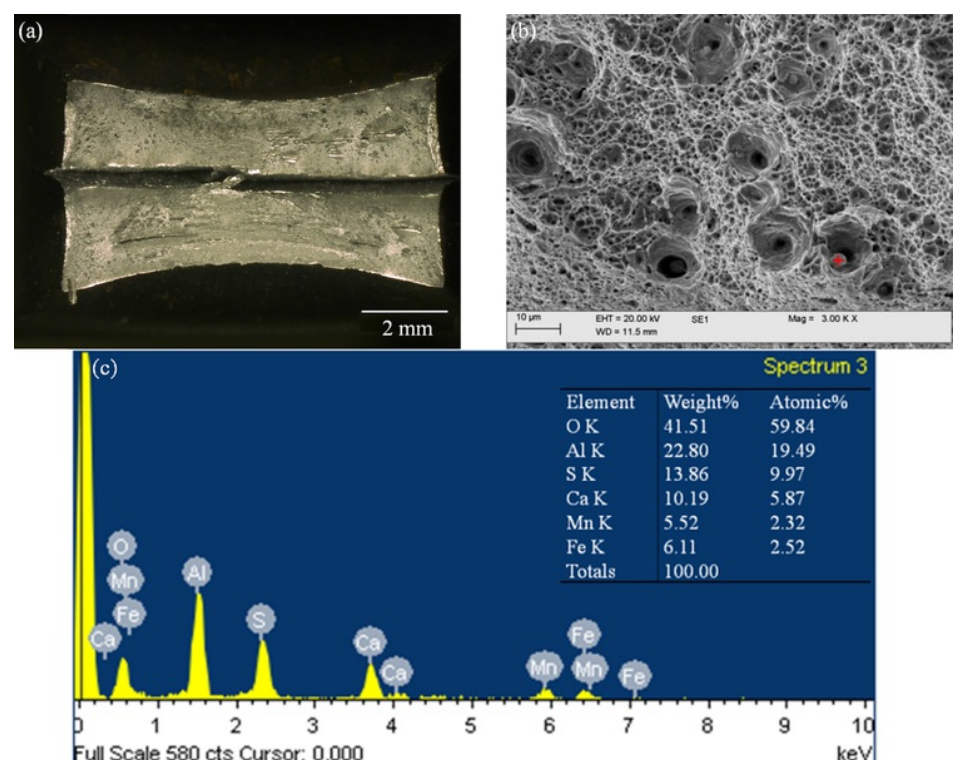

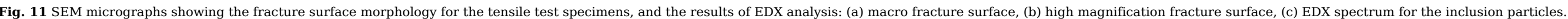
alt-text: Fig. 11

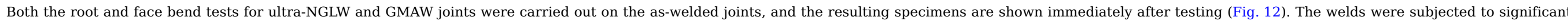

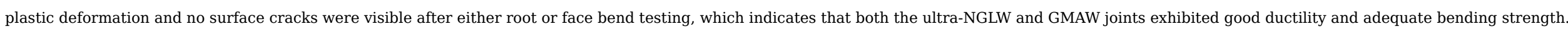

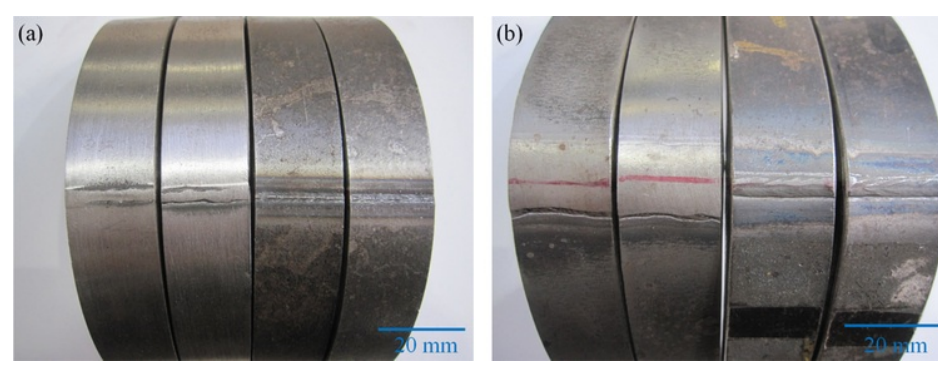

Fig. 12 Three-point bend test results, (a) ultra-NGLW samples, (b) GMAW samples. alt-text: Fig. 12

\subsection{Charpy impact properties}




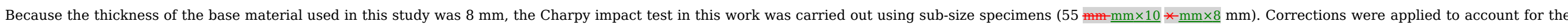

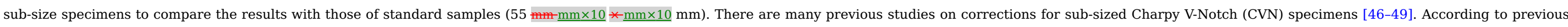

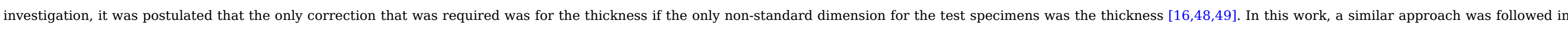
applying corrections to the energies on $8 \mathrm{~mm}$ thick specimens, i.e. by multiplying the absorbed energies by a factor of 1.25 (i.e. 10/8).

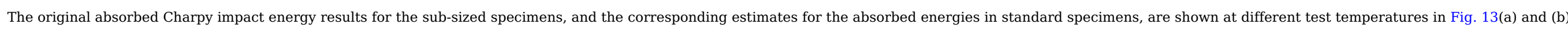

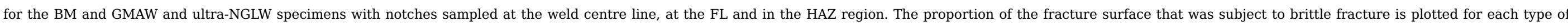
sample in Fig. 13(c) to exam the fracture mechanism.
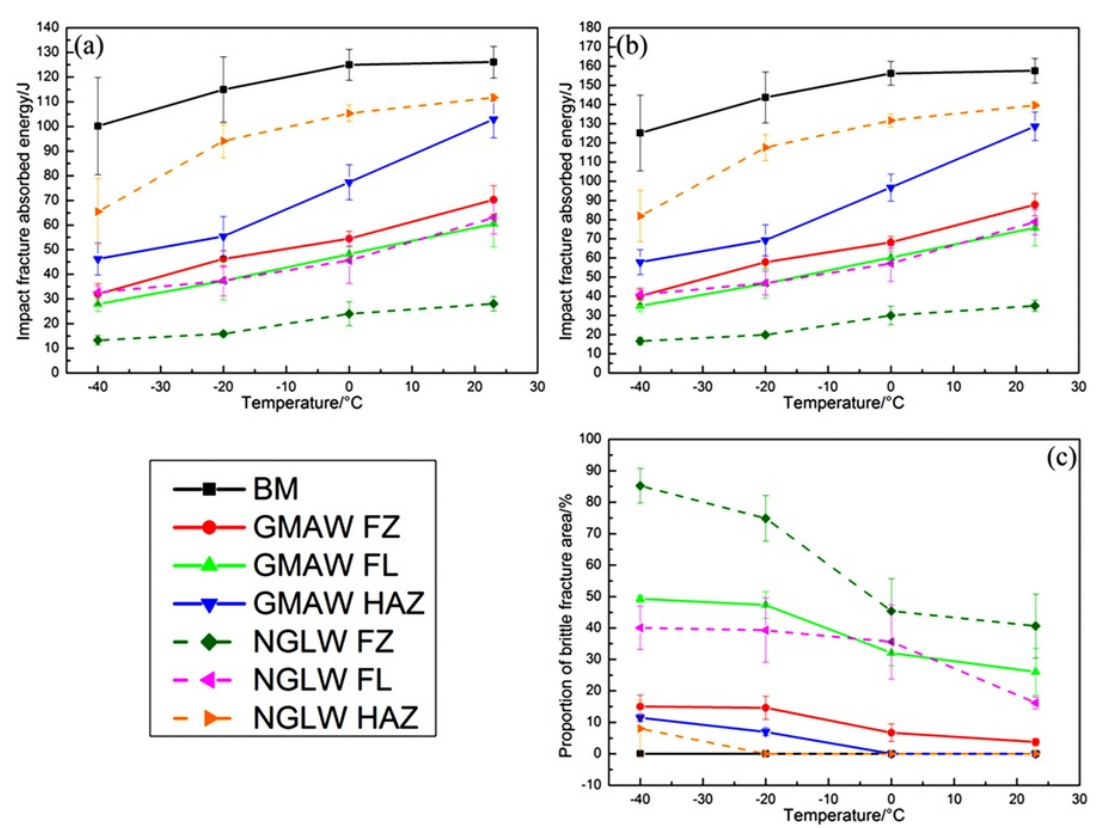

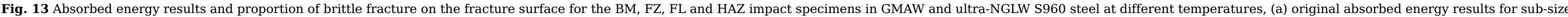
specimens ( $55 \mathrm{~mm}-\underline{\mathrm{mm} \times 10} *-\underline{\mathrm{mm} \times 8} \mathrm{~mm}$ ), (b) corresponding estimates for absorbed energies in standard-sized specimens, (c) proportion of brittle fracture on the fracture surface.

\section{alt-text: Fig. 13}

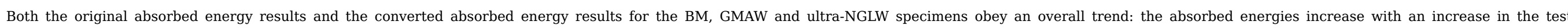

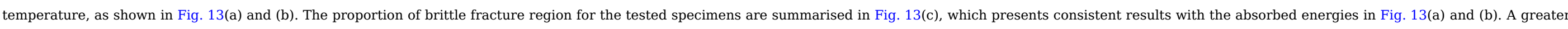

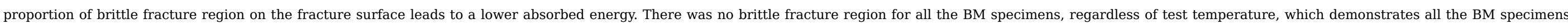
fractured in a ductile manner with good toughness.

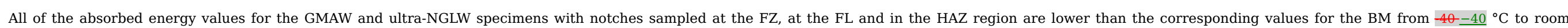
temperature. It can be observed from Fig. 13 that the GMAW joints present better impact toughness than that for the ultra-NGLW joints.

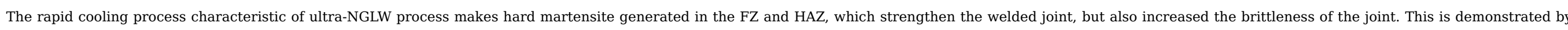

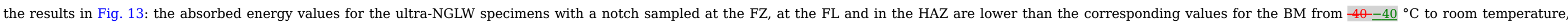

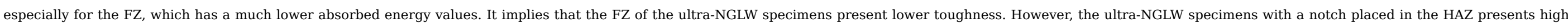




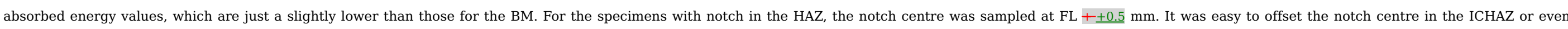

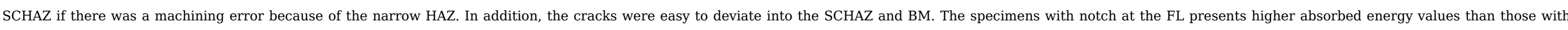

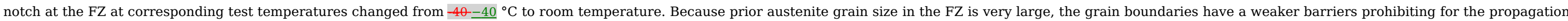
of cracks.

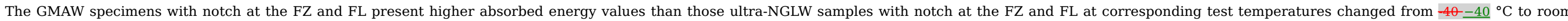

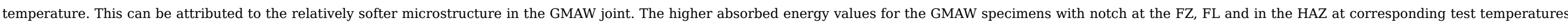

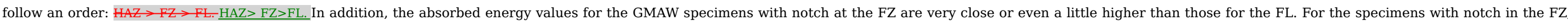

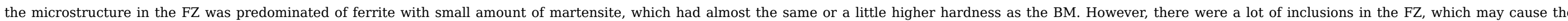

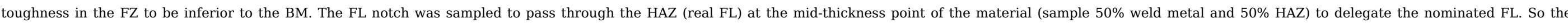

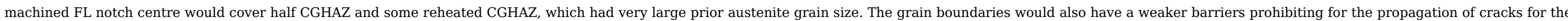

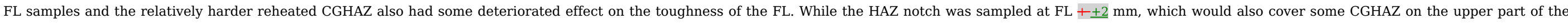

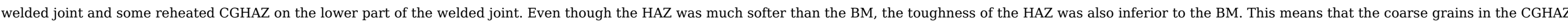

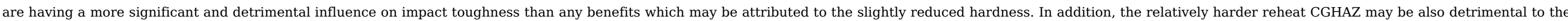
toughness of the HAZ.

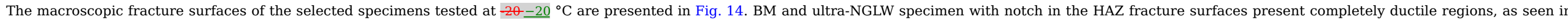

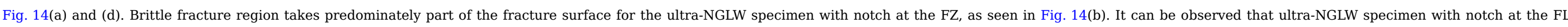

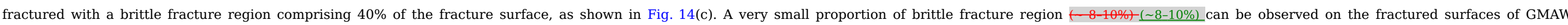

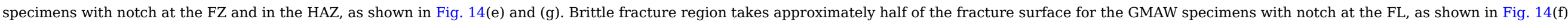




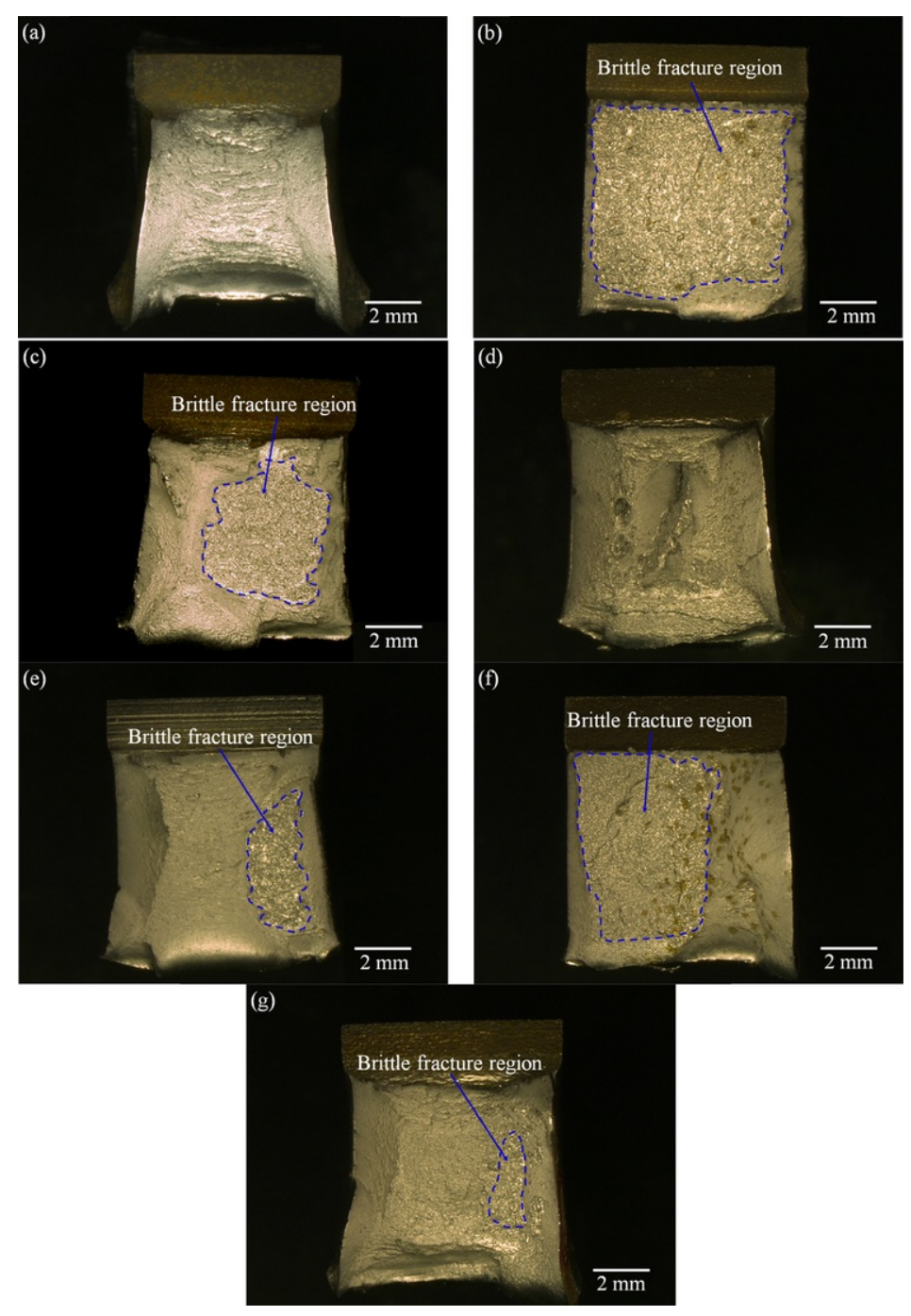

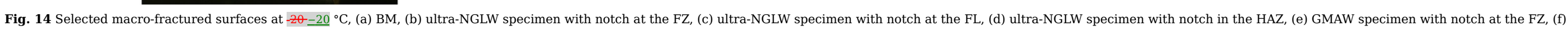
GMAW specimen with notch at the FL, (g) GMAW specimen with notch in the HAZ. alt-text: Fig. 14

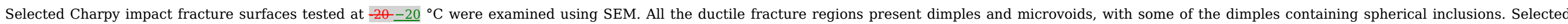

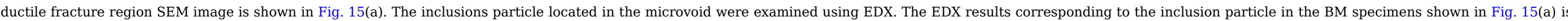

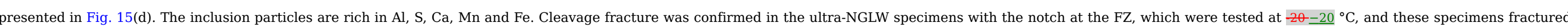

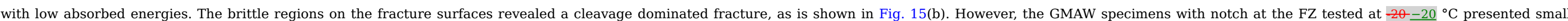

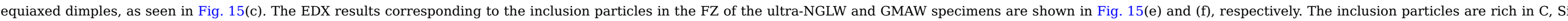
and $\mathrm{Fe}$ 

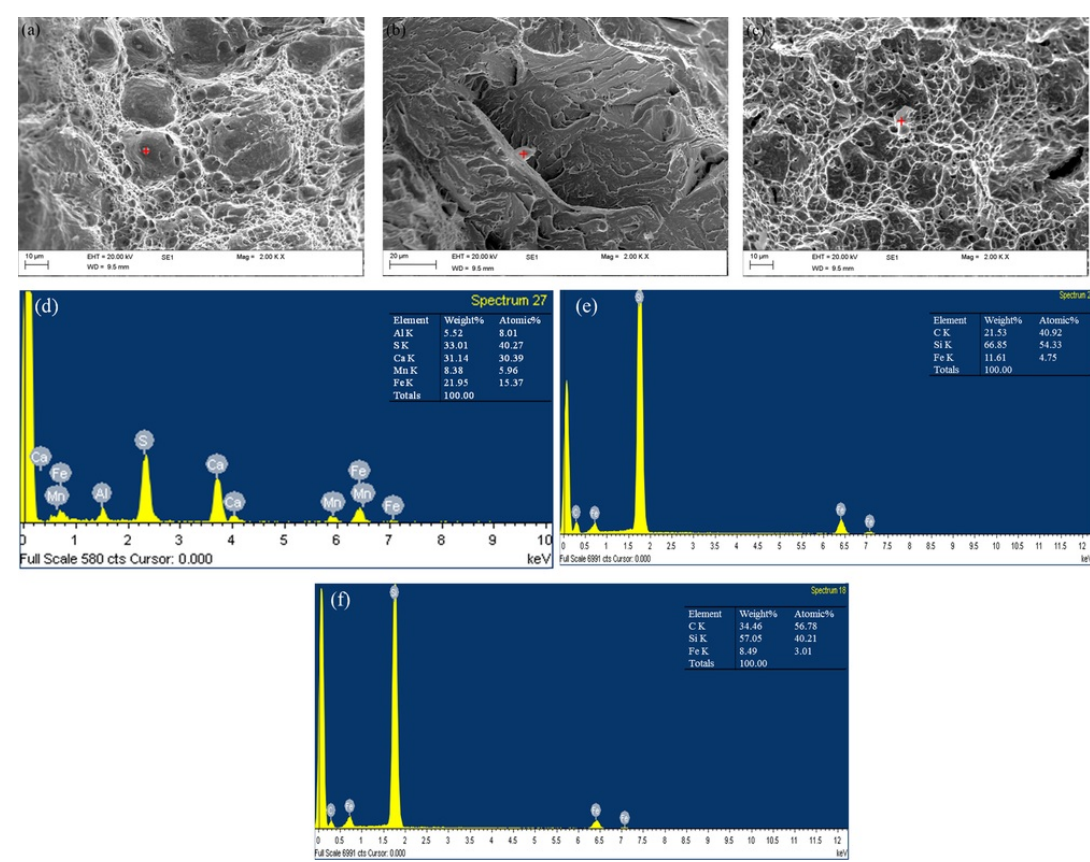

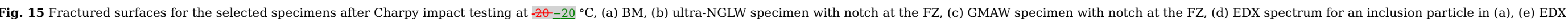
spectrum for an inclusion particle in (b), (f) EDX spectrum for an inclusion particle in (c).

alt-text: Fig. 15

\section{Conclusions}

From this investigation the following conclusions were derived:

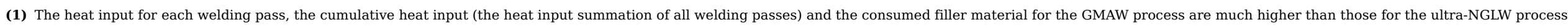

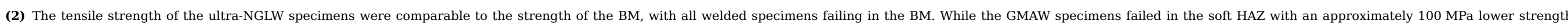

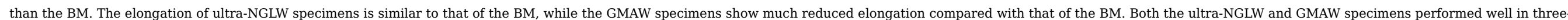
point bending tests.

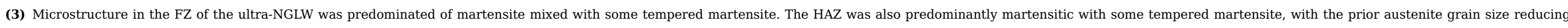

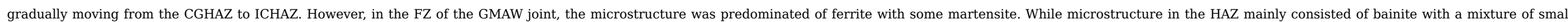
amount of martensite and tempered martensite, with the prior austenite grain size reducing gradually moving from the CGHAZ to ICHAZ.

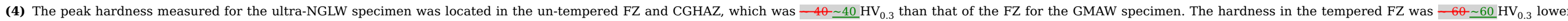

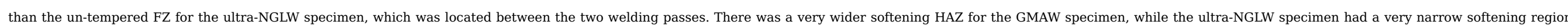
located in the SCHAZ.

(5) The GMAW joint demonstrated better impact toughness than the ultra-NGLW joint. The generation of martensite in the FZ of the ultra-NGLW joint makes the FZ brittle.

\section{Acknowledgements}




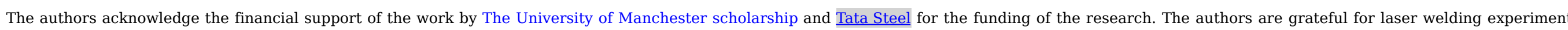

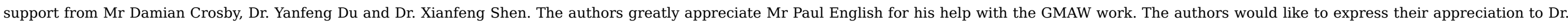
Zhu Liu and Mr Yiqiang Chen for their assistance in providing the materials characterization facilities. Thanks should be given to Dr. Matthew Roy for his help with the hardness mapping test.

\section{References}

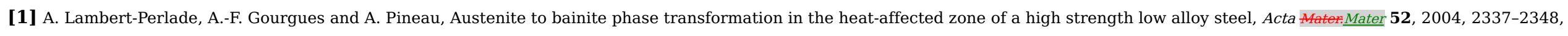
http://dx.doi.org/10.1016/j.actamat.2004.01.025.

[2] X. Cao, P. Wanjara, J. Huang, C. Munro and A. Nolting, Hybrid fiber taser Arelaser-arc welding of thick section high strength low alloy steel, Mater. Des.Mater Des 32, 2011, 3399-3413, http://dx.doi.org/10.1016/j.matdes.2011.02.002.

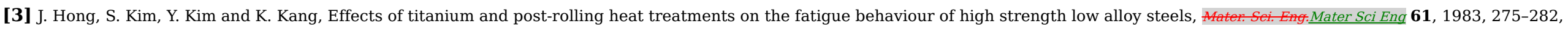
http://dx.doi.org/10.1016/0025-5416(83)90110-6.

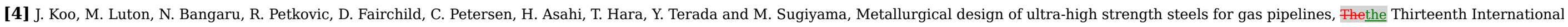
Offshore and Polar Engineering Conference, 2003, International Society of Offshore and Polar Engineers, 10-18.

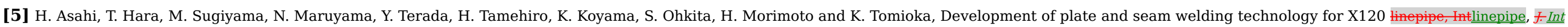
IOffshore Polar Eng 14, 2004, 153-159.

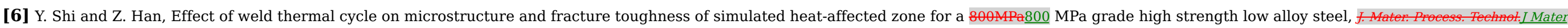
Process Technol 207, 2008, 30-39, http://dx.doi.org/10.1016/j.jmatprotec.2007.12.049.

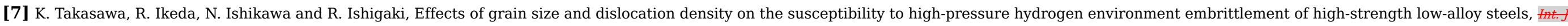
Hydronerg.Int J Hydrog Energ 37, 2012, 2669-2675, http://dx.doi.org/10.1016/j.ijhydene.2011.10.099.

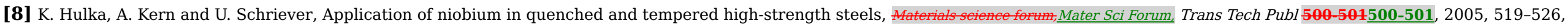
http://dx.doi.org/10.4028/www.scientific.net/MSF.500-501.519.

[9] M. Ghosh, K. Kumar and R. Mishra, Analysis of microstructural evolution during friction stir welding of ultrahigh-strength steel, Seriptater:Scr Mater 63, 2010, 851-854, http://dx.doi.org/10.1016/j.scriptamat.2010.06.032.

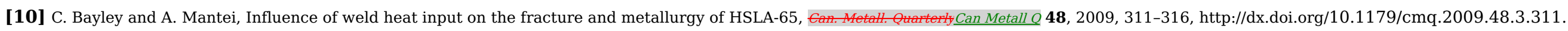

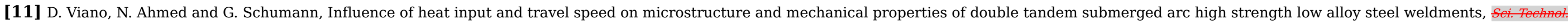
Weld. Joi:Sci Technol Weld Joi 5, 2000, 26-34, http://dx.doi.org/10.1179/stw.2000.5.1.26.

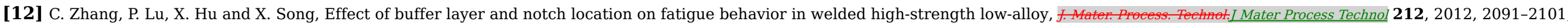
http://dx.doi.org/10.1016/j.jmatprotec.2012.05.014.

[13] M.N. Esfahani, J. Coupland and S. Marimuthu, Numerical simulation of alloy composition in dissimilar laser welding, f. Mater. Proess. Technol.JMater Process Technol 224, 2015, 135-142, http://dx.doi.org/10.1016/j.jmatprotec.2015.05.005.

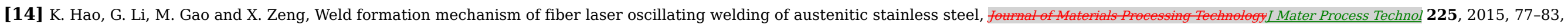
http://dx.doi.org/10.1016/j.jmatprotec.2015.05.021. 
[15] M. Sokolov, A. Salminen, M. Kuznetsov and I. Tsibulskiy, Laser welding and weld hardness analysis of thick section S355 structural steel, Mater. Des:Mater Des 32, 2011, 5127-5131, http://dx.doi.org/10.1016/j.matdes.2011.05.053.

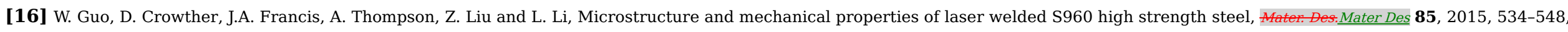
http://dx.doi.org/10.1016/j.matdes.2015.07.037.

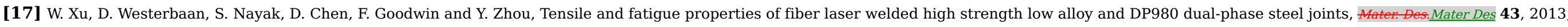
373-383, http://dx.doi.org/10.1016/j.matdes.2012.07.017.

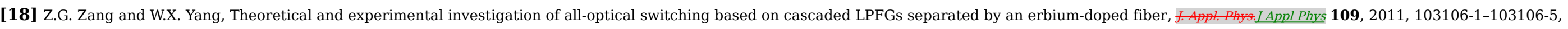
http://dx.doi.org/10.1063/1.3587358.

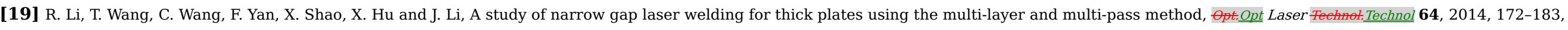
http://dx.doi.org/10.1016/j.optlastec.2014.04.015.

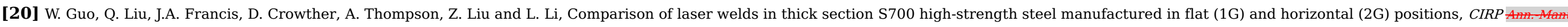
Fechn:Ann -Manuf Technol 64, 2015, 197-200, http://dx.doi.org/10.1016/j.cirp.2015.04.070.

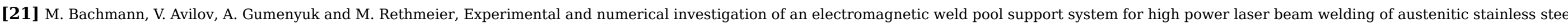
f. Mater. Pross. Teerol.J Mater Process Technol 214, 2014, 578-591, http://dx.doi.org/10.1016/j.jmatprotec.2013.11.013

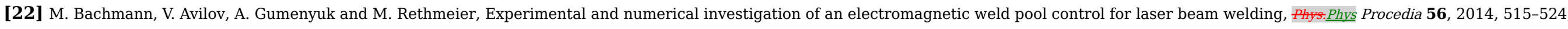
http://dx.doi.org/10.1016/j.phpro.2014.08.006.

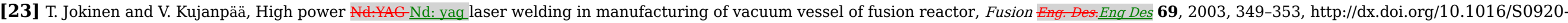
3796(03)00071-1.

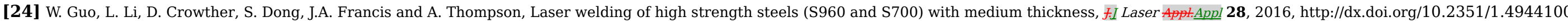

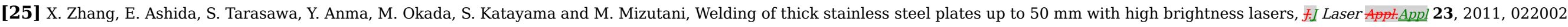
http://dx.doi.org/10.2351/1.3567961

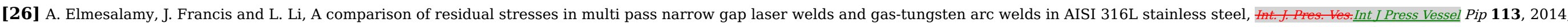
49-59, http://dx.doi.org/10.1016/j.ijpvp.2013.11.002.

[27] D. Dittrich, R. Schedewy, B. Brenner and J. Standfuß, Laser-multi-pass-narrow-gap-welding of hot crack sensitive thick aluminum plates, Phys.Phys Procedia 41, 2013, 225-233, http://dx.doi.org/10.1016/j.phpro.2013.03.073.

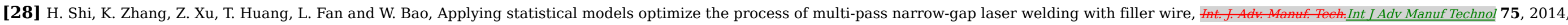
279-291, http://dx.doi.org/10.1007/s00170-014-6159-y.

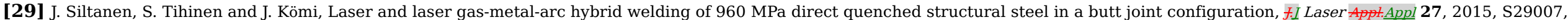
http://dx.doi.org/10.2351/1.4906386.

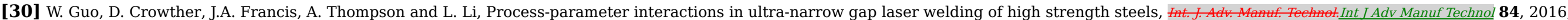
2547-2566, http://dx.doi.org/10.1007/s00170-015-7881-9. 
[31] J. DuPont and A. Marder, Thermal efficiency of arc welding processes,

[32] P. Fuerschbach, Measurement and prediction of energy transfer efficiency in laser beam welding, weld. J.Weld J 75, 1996, 15s-25s.

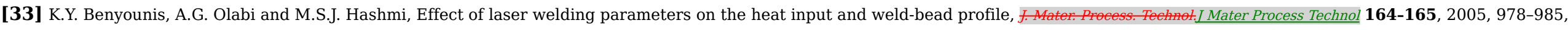
http://dx.doi.org/10.1016/j.jmatprotec.2005.02.060.

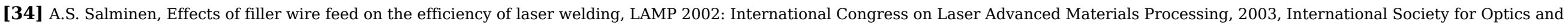
Photonics, 263-268.

[35] D. Farichild, N. Bangaru, J. Koo, P. Harrison and A. Ozekcin, A study concerning intercritical HAZ microstructure and toughness in HSLA steels, Weld. f.Weld J 70, 1991, 321. s-329. s.

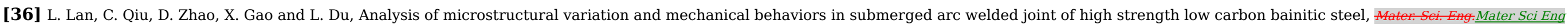
A 558, 2012, 592-601, http://dx.doi.org/10.1016/j.msea.2012.08.057.

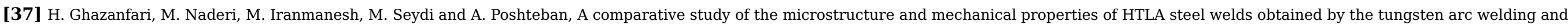
resistance spot welding, Mater. Sei. Eng.Mater Sci Eng A 534, 2012, 90-100, http://dx.doi.org/10.1016/j.msea.2011.11.046.

[38] K. Poorhaydari, B. Patchett and D. Ivey, Transformation twins in the weld HAZ of a low-carbon high strength microalloyed steel, Mater. Sei. Eng:Mater Sci Eng A 435, 2006, 371-382, http://dx.doi.org/10.1016/j.msea.2006.07.055.

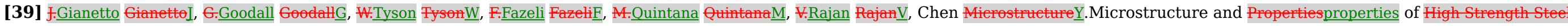

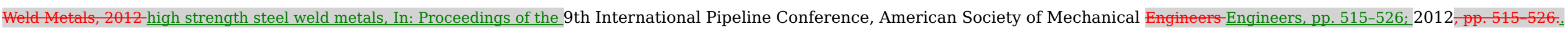

[40] Y. Han, H. Jing and L. Xu, Welding heat input effect on the hydrogen permeation in the X80 steel welded joints, Mater. Chem. Physs.Mater Chem Phys 132, 2012, 216-222, http://dx.doi.org/10.1016/j.matchemphys.2011.11.036.

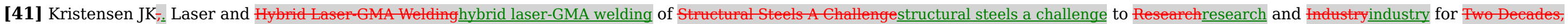
Frendstwo decades, trends in Welding Researeh 2008: welding research 2008, In: Proceedings of the 88th-th International Conference, 7 (7, pp. 645-651; 2009) pp. 645-651.

[42] S. Nayak, V.B. Hernandez, Y. Okita and Y. Zhou, Microstructure-hardness relationship in the fusion zone of TRIP steel welds, Mater. Sei. Eng.Mater Sci Eng A 551, 2012, 73-81, http://dx.doi.org/10.1016/j.msea.2012.04.096.

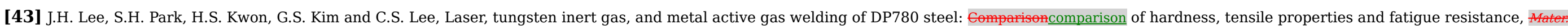
Des:Mater Des 64, 2014, 559-565, http://dx.doi.org/10.1016/j.matdes.2014.07.065.

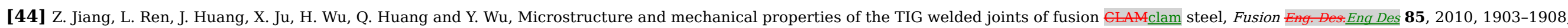
http://dx.doi.org/10.1016/j.fusengdes.2010.06.019.

[45] K. Bang and W. Kim, Estimation and prediction of HAZ softening in thermomechanically controlled-rolled and accelerated-cooled steel, weld. J.Weld] 81, 2002, 174-S-179-S.

[46] K. Wallin, Upper shelf energy normalisation for sub-sized Charpy-V specimens, fnt. J. Pres. Ves.Int J Press Vessel Pip 78, 2001, 463-470, http://dx.doi.org/10.1016/S0308-0161(01)00063-1.

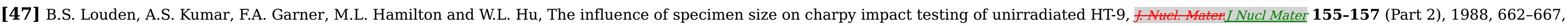
http://dx.doi.org/10.1016/0022-3115(88)90391-1.

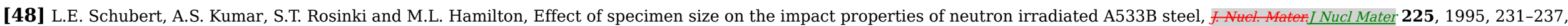
http://dx.doi.org/10.1016/0022-3115(95)00052-6. 


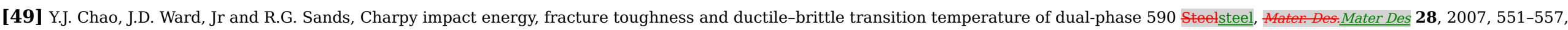
http://dx.doi.org/10.1016/j.matdes.2005.08.009.

\section{Highlights}

- Narrow gap laser welding (NGLW) was carried out on the new S960 high strength steel.

- The microstructures of NGLW and GMAW of S960 high strength steel were characterised.

- The NGLW joints displayed better tensile properties than the GMAW joints.

- The GMAW joints exhibited better impact toughness than the ultra-NGLW joints.

\section{Queries and Answers}

Query:

Please validate the sponsor name "Tata Steel, India".

Answer: The sponsor name is Tata Steel, UK.

Query:

Please provide Grant number for Grant sponsor's "The University of Manchester scholarship" and "Tata Steel".

Answer: There is no Grant number for these sponsors.

Query:

Please provide the place of publication in Refs. [4] and [34] if available.

Answer: Ref. [4] was published in Honolulu, Hawaii, USA. Ref. [35] was published in Osaka, Japan. 